\title{
Temperature Dependent Sex Differentiation In Rainbow Trout (Oncorhynchus Mykiss)
}

\author{
Dissertation \\ for the Doctoral Degree \\ at the Faculty of Agricultural Science, \\ Georg-August-University Göttingen
}

Andreas Magerhans

born in Göttingen (Germany)

Göttingen, April 2009 
D 7

1. Referee: Prof. Dr. G. Hörstgen-Schwark

2. Co-referee: Prof. Dr. Dr. U. ter Meulen

Date of disputation: $20^{\text {th }}$ May 2009 
Meinen Eltern 


\section{Table of contents}

Tables and figures $\quad$ V

Zusammenfassung 1

Summary 4

$\begin{array}{llc}\text { Chapter } 1 & \text { Introduction } & 6\end{array}$

Introduction of the species "rainbow trout" 8

$\begin{array}{ll}\text { Overview of the global production of salmonids } & 10\end{array}$

Temperature dependent sex determination and differentiation $\quad 12$

$\begin{array}{ll}\text { Scope of the thesis } & 18\end{array}$

Chapter 2 Effect of rearing temperatures post hatching on sex ratios of rainbow trout (Oncorhynchus mykiss) populations 19

$\begin{array}{ll}\text { Abstract } & 20\end{array}$

Introduction $\quad 20$

$\begin{array}{ll}\text { Materials and methods } & 21\end{array}$

Results 23

$\begin{array}{ll}\text { Discussion } & 25\end{array}$

Chapter 3 Selection experiments to alter the sex ratio in rainbow trout (Oncorhynchus mykiss) by means of temperature treatment 32

$\begin{array}{ll}\text { Abstract } & 33\end{array}$

Introduction 33

Materials and methods $\quad 34$

$\begin{array}{ll}\text { Results } & 37\end{array}$

Discussion $\quad 39$

Chapter 4 General Discussion $\quad 44$

$\begin{array}{ll}\text { References } & 50\end{array}$

$\begin{array}{ll}\text { Appendix } & 59\end{array}$

$\begin{array}{ll}\text { Acknowledgement } & 73\end{array}$ 


\section{Tables and figures}

\section{Chapter 1}

Table 1 Physiological demands of the rainbow trout 9

Table 2 Ovarian development of rainbow trout from 50 to $250 \quad 15$ days post fertilization

Figure 1 Global production of rainbow trout from 1950 to 2006 in thousand tons

Figure 2 European production of large rainbow trout in thousand tons from 1998 to 2005

Figure 3 Changes in the total number of germ cells (in 1000) in the gonads of rainbow trout embryos during 11 weeks after hatching at a rearing temperature of $10{ }^{\circ} \mathrm{C}-11^{\circ} \mathrm{C}$

\section{Chapter 2}

Table 1 Effects of temperature treatment $\left(18{ }^{\circ} \mathrm{C}\right.$ for 30 days $)$ on progeny sex ratios from randomly selected broodstock from six rainbow trout populations

Table 2 Effects of temperature treatment $\left(18{ }^{\circ} \mathrm{C}\right.$ for 30 days $)$ on sex ratios of full sib progenies produced from repeated single pair matings within four different rainbow trout populations

Table 3 Effects of temperature treatment $\left(18{ }^{\circ} \mathrm{C}\right.$ for 30 days $)$ on sex ratios of half sib progenies produced from single pair matings of individual fish of different rainbow trout populations

\section{Chapter 3}

Table 1 Survival rate, number of fish sexed and sex ratios of treatment

$\left(18^{\circ} \mathrm{C}\right.$ for 30 days $)$ and control groups $\left(12^{\circ} \mathrm{C}\right)$ in the base population (G0) and in the high and low line in the first generation (G1)

Table 2 Total number of families ( $n$ Total), number of families selected ( $n$ selected), proportion of families selected ( $p$ selected), realized selection differential $\left(\mathrm{S}_{\mathrm{R}}\right.$ in $\%$ females), standardized realized selection differential $\left(S_{R}\right.$ in $\left.S D\right)$, realized response to selection $\left(\Delta \mathrm{G}_{\mathrm{R}}\right)$ and standardized realized response to selection $\left(\Delta \mathrm{G}_{\mathrm{R}}\right.$ in $\left.\mathrm{SD}\right)$ in treatment groups in the high and low line in the base population (G0) and the first generation of selection (G1) 


\section{Zusammenfassung}

Die Produktion von Regenbogenforellen (Oncorhynchus mykiss) steigt seit Jahrzehnten exponential an und betrug im Jahr 2006 weltweit 500,000 t. Die Regenbogenforelle ist damit nach dem Atlantischen Lachs (Salmo salar) die wichtigste Salmonidenart weltweit. Als Süsswasserspezies mit hohen Ansprüchen an die Haltungsumwelt ist die ursprünglich von der Pazifikküste Nordamerikas stammende Regenbogenforelle heute in nahezu allen Ländern verbreitet und beim Konsumenten aufgrund ihres schmackhaften und nährstoffreichen Fleisches sehr beliebt. Hierbei hat sich auch die Nachfrage nach so genannten „Lachsforellen“, wobei es sich um Forellen mit einem Lebendgewicht von mehr als 1,2 kg handelt, in den letzten Jahren positiv entwickelt. Die Erzeugung dieser „Lachsforellen“ setzt eine relativ lange Mastzeit von 2 - 3 Jahren voraus, was bei gemischtgeschlechtlichen Beständen den Nachteil der Geschlechtsreife der Milchner ab dem zweiten Lebensjahr mit sich bringt. Dieser Umstand kann zu einer hohen Mortalität der Milchner im gemischtgeschlechtlichen Bestand sowie zu einer Wachstumsstagnation und einer negativen Beeinträchtigung der Fleischqualität führen. Aus diesem Grund werden zur Produktion von „Lachsforellen“ (> 1,2 kg) rein weibliche Fische bevorzugt.

Der vorliegende experimentelle Versuch hatte zum Ziel, eine alternative Methode zum bisher üblichen Hormoneinsatz für die Erstellung funktioneller Milchnern zu entwickeln. Funktionelle Milchner führen bei Anpaarung mit normalen Rognern zu rein weiblichen Nachkommenschaften, welche zum Zwecke der Produktion rein weiblicher Forellenbestände für die Ausmast auf hohe Körpergewichte (> 1,2 kg) wünschenswert sind. Die alternative Methode sollte in Deutschland umsetzbar sein und neben wirtschaftlichen Aspekten den hohen Qualitätsansprüchen, die der deutsche Verbraucher an deutsche Fischprodukte stellt, entsprechen.

Der hier verfolgte neue Ansatz, die Geschlechtsausprägung bei Forellen zu beeinflussen, beruhte auf der gezielten Veränderung der Haltungstemperatur während der Brütlingsphase. Eine Sensibilität der Geschlechtsausprägung gegenüber Haltungstemperaturen konnte für andere Fischarten, z.B. für Tilapien, bereits wissenschaftlich nachgewiesen werden.

Nach technischer Optimierung der Behandlungsabläufe kam eine Behandlungstemperatur von $18^{\circ} \mathrm{C}$ für 30 Tage, beginnend zwei Wochen nach Schlupf, zum Einsatz. Die Überlebensraten der Brut nach dieser Behandlungsvariante zeigten keine signifikanten 
Unterschiede zu den Kontrollwerten. Eine erhöhte Wassertemperatur während der Brütlingsphase hatte im Gegenteil eine positive Auswirkung auf das Heranwachsen der Brütlinge. Je nach verwendeter Herkunft und Familie zeigten die Behandlungsgruppen gegenüber den unbehandelten Kontrollgruppen deutlich erhöhte Weibchenanteile (von bis zu 83\%) oder deutlich niedrigere Weibchenanteile (bis zu 30\%). Die Ergebnisse der Temperaturtestung $\left(18{ }^{\circ} \mathrm{C}\right.$ für 30 Tage) von Nachkommen aus wiederholten Anpaarungen derselben Eltern variierten nur um 1 bis 6\%. Beide Elternteile, Milchner und Rogner, trugen zu den verschiedenen Geschlechterverhältnissen in den temperaturbehandelten Nachkommengruppen bei.

Aufbauend auf den erzielten Ergebnissen wurden anschließend vertiefende Untersuchungen zur Vererbbarkeit der Temperatursensibilität in Form eines Selektionsexperimentes durchgeführt. Zur Ermittlung der Temperatursensibilität wurden die Nachkommen einer Familie in eine Kontroll- und eine Behandlungsgruppe aufgeteilt und beginnend zwei Wochen nach Schlupf bei $12{ }^{\circ} \mathrm{C}$ bzw. bei $18{ }^{\circ} \mathrm{C}$ für 30 Tage aufgezogen. Die Geschlechterverhältnisse in den Behandlungs- und Kontrollgruppen wurden makrobzw. mikroskopisch nach 8 Monaten Aufzucht bestimmt. Das Selektionsmerkmal war der Weibchenanteil in der temperaturbehandelten Vollgeschwistergruppe. Ausgehend von einer Basispopulation bestehend aus 95 Familien wurden jeweils sechs Familien selektiert, die einen hohen Weibchenanteil (Selektionsdifferential für den Weibchenanteil betrug 9\%) bzw. niedrigen Weibchenanteil (Selektionsdifferential betrug -10\%) aufwiesen, und zur Erstellung zweier divergierender Linien genutzt.

Die Ergebnisse der ersten Selektionsgeneration zeigten, dass eine Selektion auf Temperatursensibilität während der Phase der Geschlechtsdifferenzierung mit dem Ziel erhöhter Weibchenanteile möglich ist. In der 1. Selektionsgeneration wies die für einen erhöhten Weibchenanteil selektierte Linie (HL) einen durchschnittlichen Weibchenanteil von $57,6 \% \pm 4,7$ nach der Temperaturbehandlung auf, während der Weibchenanteil bei den entsprechenden Vollgeschwistern in den Kontrollen $\left(12{ }^{\circ} \mathrm{C}\right)$ bei $49,5 \% \pm 1,8$ lag. Die für einen niedrigen Weibchenanteil selektierte Linie (NL) zeigte in der 1. Selektionsgeneration einen durchschnittlichen Weibchenanteil von 44,5\% \pm 4,3 mit einem korrespondierenden Wert in der Kontrolle von 49,6\% \pm 2 , 1 . Somit konnte gezeigt werden, dass die temperaturabhängige Geschlechtsausprägung einer genetischen Komponente unterliegt, ausgewiesen durch eine realisierte Heritabilität (gemittelt über beide Linien) $v$ von $\mathrm{h}_{\mathrm{R}}{ }_{\mathrm{R}}=$ 0,67 . 
Eine mögliche Alternative, rein weibliche Nachkommenschaften zu erzeugen, wäre es, mit Hilfe der bereits in diesem experimentellen Versuch erfolgreich getesteten meiotischen Gynogenese und einer anschließenden Temperaturbehandlung der Nachkommen, funktionelle Milchner zu erstellen. Funktionelle Milchner erbringen in Anpaarung mit normalen Rognern weibliche Nachkommenschaften. Durch diese alternative Methode wäre es möglich, bei der Ausmast von Regenbogenforellen auf hohe Stückgewichte über 1,2 $\mathrm{kg}$ den sonst üblichen Einsatz von Hormonen zwecks Erstellung funktioneller Milchner zu umgehen, um eingeschlechtliche weibliche Populationen zu erzeugen. 


\section{Summary}

The commercial production of rainbow trout (Oncorhynchus mykiss) increased exponentially in the decades following the 1950 s, reaching a level of $550.000 \mathrm{t}$ in 2006 . It is the most produced species within salmonids after the Atlantic salmon (Salmo salar) worldwide. Rainbow trout is a freshwater species and it is highly sensitive with regard to all water parameters, especially oxygen content. Rainbow trout originally came from the Pacific coast of North America and were imported to Europe at the end of the $19^{\text {th }}$ century, consequently this species is located all over the world today. It became highly popular with consumers due to its nutritious and delicate meat. This increased also the demand of large size rainbow trout $(>1.2 \mathrm{~kg})$ over the last years. The production of large rainbow trout lasts between two to three years with male rainbow trout beginning to mature at approximately an age of two years, one year earlier than the females. This circumstance can lead to problems when rainbow trout stocks are of mixed sex, because at this stage the fish have not reached a body weight of more than $1.2 \mathrm{~kg}$. The onset of maturity in male rainbow trout has negative effects on the meat quality and growth performance, due to an increased susceptibility and receptivity to fungal and bacterial diseases during the spawning season. This raises the mortality rate in male rainbow trout, which is why all-female stocks are preferred for production of large size rainbow trout $(>1.2 \mathrm{~kg})$.

The aim of the project is the evaluation of an alternative to the usage of hormonal treatment in order to produce rainbow trout neo-males for an all female production by mating these neo-males to normal rainbow trout females. As a precondition, the developed alternative, aside to economical aspects, should be legally applicable in Germany and should fulfil the high market demands for fish products. The pursued approach to influence the sex differentiation in rainbow trout is based on the modification of the rearing temperature post hatching, during the early alevin stage. This has been scientifically proven to be effective in other fish species, e.g. Nile tilapia (Oreochromis niloticus).

After the technical optimization of the treatment procedure a temperature treatment of $18^{\circ} \mathrm{C}$ for 30 days was applied to ongoing experiments starting two weeks post hatching. The survival rates of the fry after temperature treatment did not differ significantly from the corresponding control groups, however, the higher temperatures showed a positive influence to the growth performance of the alevins. Depending on the population and family, the applied temperature treatments led to a significant increase in the percentage of females (up to $83 \%$ ) or to a significant decrease in female percentages (down to $30 \%$ ) 
in comparison to the untreated full sib control groups. The results obtained from repeated matings of identical mating partners differed only by 1 to $6 \%$ females in their offspring. Both, female and male spawners, contributed to the different sex ratios in temperature treated groups.

Taking the initially obtained results as a base, further investigations were conducted concerning the heritability of thermo-sensitivity during sex differentiation in the form of a selection experiment. In order to measure the thermo-sensitivity on sex differentiation, the progenies were divided into a treatment and a control group. Both groups were reared separately two weeks post hatching, in temperatures of $12{ }^{\circ} \mathrm{C}$ and respectively 18 ${ }^{\circ} \mathrm{C}$ for 30 days. They were subjected to sexing after a rearing time of approximately 8 months in order to determine macroscopically or microscopically the sex ratio of the group. The selection criterion was the female percentage of the temperature treated full sib group. The base population consisted of 95 tested families, of which 6 families each were selected showing an increased female proportion (high line: selection differential of $9 \%$ ) in the offspring and respectively a decreased female proportion (low line: selection differential of $-10 \%$ ) in order to create two divergent lines (a high and a low line).

The results of the first generation showed that selection using thermo-sensitivity on sex differentiation is possible. In the high line the first generation of selection showed an increased mean female proportion of $57.6 \% \pm 4.7$ after temperature treatment, however, the corresponding value for the controls was $49.5 \% \pm 1.8$. The first generation of selection of the low line showed a decreased female proportion of $44.5 \% \pm 4.3$ after temperature treatment with the corresponding value of the control groups at $49.6 \% \pm 2.1$. The results indicated that the rearing temperature during the early alevin stage in rainbow trout can influence the sex ratio. Rainbow trout are known to have a genetic background of thermo-sensitivity depending to the population and the mating partners shown by an averaged heritability of both lines of $\mathrm{h}^{2}{ }_{\mathrm{R}}=0.67$.

A potential alternative to produce all female progenies could be achieved by a meiotic gynogenesis and a following temperature treatment of gynogenetic progenies to obtain functional males. The functional males deliver all female progenies when they are mated to normal females. This procedure provides an alternative technique for the production of large rainbow trout with body weights above $1.2 \mathrm{~kg}$, without using the common method of hormones that produce neo-males to attain all-female progenies when these neo-males are mated to normal females afterwards. 
Chapter 1

Introduction 
In many countries, especially in the developing countries, fish is an utmost important source of protein for the human population. The challenges of the continuously decreasing marine capture benefits of fish, mussels, crabs and other aquatic species are wellknown and since the 1950s scientists have been seeking a solution. Fish have the ability to utilize feed to a highly effective level, in comparison to warm blooded animals like pigs and cattle which is why aquaculture has become a very important role in providing the necessary amount of protein in the human diet globally.

The aquaculture sector is increasing very rapidly and it is gaining more importance in relation to other established production systems such as the classical agricultural milk and meat production, which is linked to the usage of a huge amount of good farm land and other valuable resources. For these reasons and in order to be able to face the problems of the future successfully, it would be necessary to keep the aquaculture sector growing.

In order to produce large rainbow trout with weights above $1.2 \mathrm{~kg}$ it is necessary to develop a method that is, aside to economical aspects, legally applicable also in Germany, which can fulfil the high quality demands for fish products for the western European consumers. This makes it necessary to develop another consumer-friendly procedure that rivals with the common practise of feeding rainbow trout alevins with hormones during the early life stage for the production of functional males. Such functional rainbow trout males can produce all-female progenies when they are mated to normal females.

The aim of this study was the testing of an alternative method where temperature treatment was used instead of the usual but questionable hormonal approach for the production of functional males. As possible alternative a temperature treatment of $18{ }^{\circ} \mathrm{C}$ for 30 days on rainbow trout alevins two weeks post hatching was tested in order to influence the sex ratio of the treated progenies. 


\section{Introduction of the species "rainbow trout"}

The species rainbow trout (O. mykiss, Walbaum, 1792) is assigned taxonomically to the order of Salmoniformes, to the family of salmonids (Salmonidae) and to the genus of Oncorhynchus (Bohl, 1999). The genus Oncorhynchus represents the salmonids which originally belong to the hemisphere of the Pacific Ocean like rainbow trout, silver salmon and the Japanese salmon. The native area of rainbow trout is the Pacific Coast of North America beginning from Alaska in the North until the northern Pacific Coast of Mexico (Smith, 1989).

The time when maturity occurs is very different between fish species (Pillay, 1990). It depends on the species as well as the environmental conditions prevailing at the current place. This is the reason why fish that are exposed to different environmental conditions can mature at different ages, even if they are of the same species (Wotton, 1982). In the northern latitudes salmonid species, in particular rainbow trout male spawners, mature at the age of two years whereas female rainbow trout spawners mature at three years (Bohl, 1999). This means that males roughly become mature more or less one year earlier than the females (McKay et al., 1986), depending on the genotype of the fish (Steffens, 1981). The evolutionary reason why the female rainbow trout mature one year later in comparison to their male counterparts is - by following the hypothesis of Darwin - that for the production of ripe eggs much more body volume is necessary than for the production of the sperm by the male rainbow trout (McCormick and Naiman, 1984). For this reason, body weight and many environmental parameters such as temperature and the nutritional conditions are responsible for the start of the maturity (Bohl, 1999). The reproduction of rainbow trout is strictly seasonal and bounded to winter months (October to April) in northern latitudes where the spawners can be divided into early, middle and late spawners depending to the month of their readiness to spawn (Purdom, 1995).

Rainbow trout were originally imported from North America to Europe and to all other countries around the world since 1880s, in order to become a good pond fish for aquacultural purposes and recreational angling. For rainbow trout it is only possible to spawn naturally in the native area on the Pacific Coast of North America, so that it has to be reproduced artificially by stripping the gonads from their bodies during spawning season 
and by artificial hatching of the fertilized eggs in an incubator (FAO, 2008a) in Europe and all other countries outside their native area.

As a result of the wide exportation of rainbow trout not only in countries of the northern latitudes but also in the uplands of many tropical and subtropical countries of Asia, East Africa and South America, is that many local domesticated strains have been developed all over the world.

The rainbow trout is described as a hardy fish which is very fast growing, tolerant to a wide range of environmental parameters and is capable to accept many different habitats ranging from an anadromous way of life, i.e. the rainbow trout strain lives in the ocean and only comes back to gravel-bottomed and well-oxygenated rivers and streams with a fast water flow in the spawning season, to lakes continuously inhabited by the rainbow trout strain. However, although this species is able to tolerate a vast range of temperature and suboptimal water conditions, in order to spawn, it has to reach an optimal feed conversion ratio, or to attain a high increase in weight, the temperature and all other environmental parameters have to be within a narrow range (Table 1), so that efficient and productive culturing of this species can be reached (FAO, 2008a).

Table 1: Physiological demands of the rainbow trout (range of swimming fry to broodstock fish) (FAO, 2008a)

\begin{tabular}{|c|c|}
\hline Environmental parameters & Values \\
\hline Optimal water temperature & $9{ }^{\circ} \mathrm{C}-17{ }^{\circ} \mathrm{C}$ \\
\hline Dissolved Oxygen & Near saturation \\
\hline $\mathrm{CO}_{2}-$ content $(\mathrm{mg} / \mathrm{l})$ & $<2.0 \mathrm{mg} \mathrm{O} / \mathrm{l}$ \\
\hline $\mathrm{ph}-$ value & $6,5-8,5($ neutral $)$ \\
\hline Alkalinity (as CaCo 3$)$ & $10-400 \mathrm{mg} / \mathrm{l}$ \\
\hline Manganese & $<0,01 \mathrm{mg} / 1$ \\
\hline Iron/zinc/copper & $<1,0 /<0,05 /<0,006 \mathrm{mg} / 1$ \\
\hline
\end{tabular}




\section{Overview of the global production of salmonids}

The global production of salmonids has more than doubled in the decade from 1994 (814.102 t) to 2004 (1.978.109 t), but only three species are economically important: Atlantic salmon (Salmo salar), rainbow trout (O. mykiss) and the silver salmon $(O$. kisutch). Under these the Altantic salmon is the most important species with more than 1.3 million tons harvested in the year 2006 , which is more than $60 \%$ of the whole salmonid production by this species. Rainbow trout is the second most important salmonid with a volume of more than a half million tons produced worldwide. This is followed by the silver salmon, which reached an annual global production of 0.133 million tons in 2006. All three species together formed more than $90 \%$ of the whole salmonid production worldwide. The production of cultivated rainbow trout has grown exponentially from 1950 until today (Figure 1).

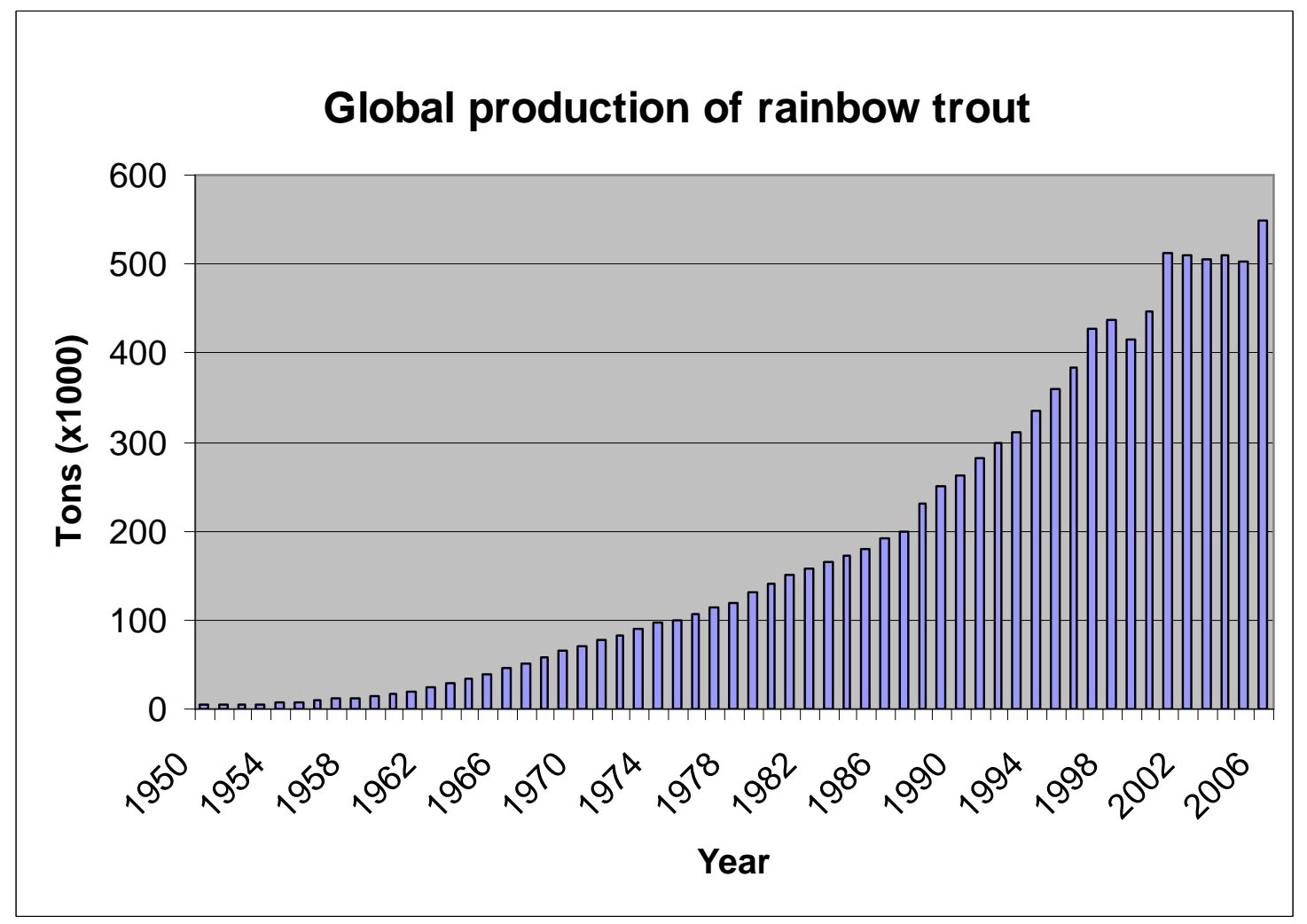

Figure 1: Global production of rainbow trout from 1950 to 2006 in thousand tons (FAO, 2008b).

This is particularly due to high growth rates in Europe and Chile who are currently the top producers of rainbow trout. Their production of rainbow trout has increased by up to $330 \%$ in only one decade, from 32.866 t (1994) to 109.578 t (2003). Today, Chile pro- 
duces more than $20 \%$ of the global rainbow trout production. Furthermore, in recent years there has been a slight increase in the production within European countries such as France, Italy, Denmark, Germany and Spain, in order to supply the domestic markets, as well as an increase in the use of marine-culture cages in Norway and Chile, which has raised the amount exported. In Europe, Norway is the top producer of rainbow trout, where production increased from $14.367 \mathrm{t}$ (1994) to $69.128 \mathrm{t}$ (2003).

Large rainbow trout (>1.2 kg) production has also increased in recent years (Figure 2). Again, Norway is on the top position in this field with an increase of $22 \%$ from $47.000 \mathrm{t}$ (1998) to $60.000 \mathrm{t}$ (2005). However, there were considerable decreases in large rainbow trout production between 1998 to 2005 in Finland (from 16.500 t down to 11.000 t), in Denmark (from $7.500 \mathrm{t}$ down to $6.000 \mathrm{t}$ ) and in Sweden (from $6.500 \mathrm{t}$ to $3.000 \mathrm{t}$ ). The other countries in Figure 2 remain more or less in stagnation of large rainbow trout production.

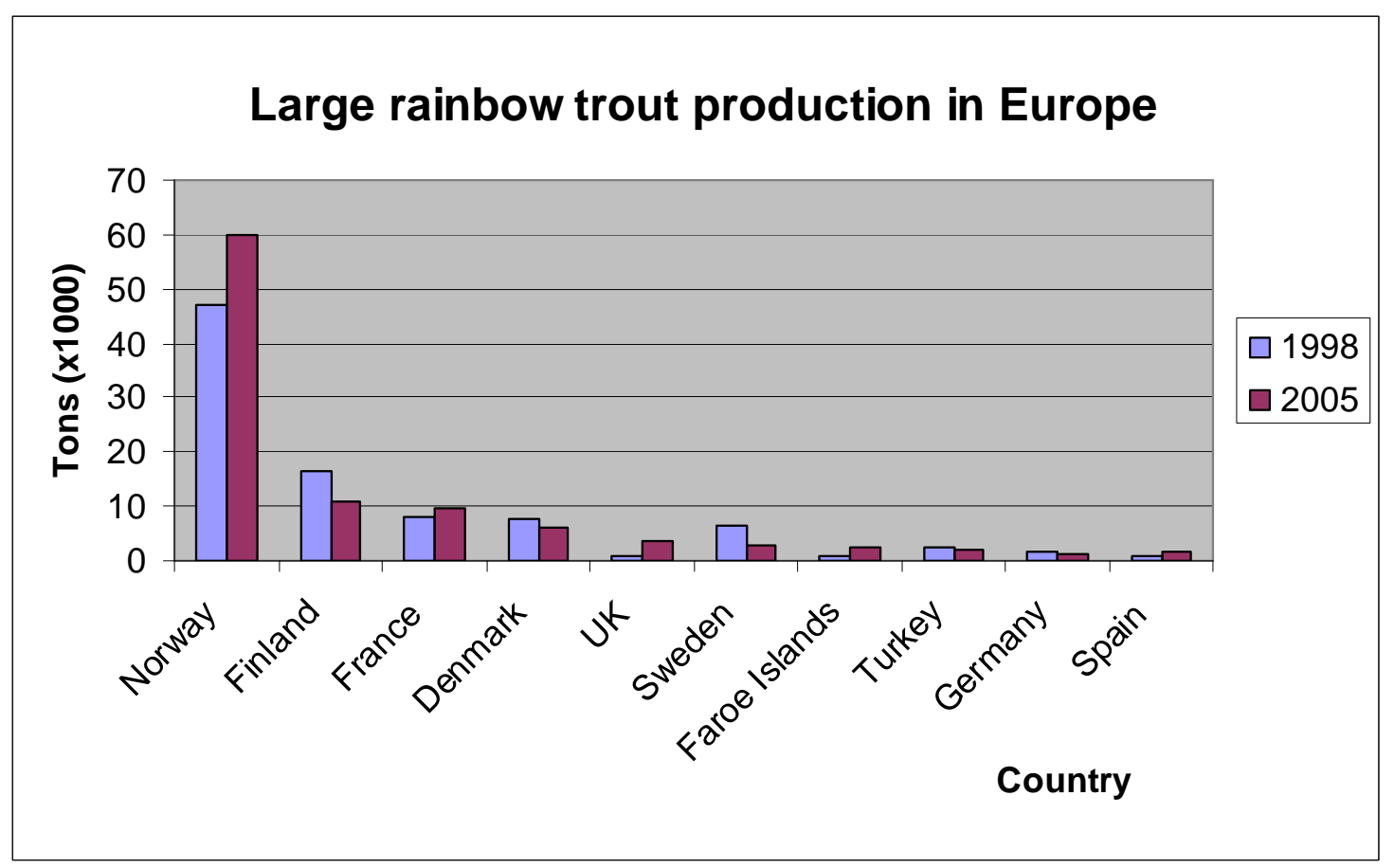

Figure 2: European production of large rainbow trout in thousand tons from 1998 to 2005 (FEAP, 2007). 


\section{Temperature dependent sex determination and differentiation}

The theory of evolution of sex ratios by Fisher (1930) states that natural selection should favour the offspring of those mothers and fathers which invest equally in male and female offspring. But in reality offspring with biased sex ratios in one or the other direction appear. A lot of studies have been conducted and reported since then that distorted sex ratios can be attributed to interferences of environmental factors for example $\mathrm{pH}$ (Heiligenberg, 1965; Rubin, 1985), stocking density in containers (Docker and Beamish, 1994; Krueger and Oliveira, 1999), maternal dominance (Grant, 1996), parental conditions (Trivers and Willard, 1973), incubation temperatures in reptiles (Piau, 1972; Bull and Vogt, 1979, Yntema, 1979; Bull 1980; Ferguson and Joanen, 1982; Bulmer, 1987; Gutzke and Crews, 1988) and alevin rearing temperatures in fishes (Conover and Kynard, 1981; Conover and Heins, 1987a, b; Baroiller et al., 1993, 1995a, b; Craig et al. 1996; Abucay et al., 1999; Azuma et al., 2004; Tessema et al., 2006; Wessels and Hörstgen-Schwark, 2007).

Density is known to be a cause for distorted sex ratios in some fishes. For instance Docker and Beamish (1994) reported in Brook Lamprey (Lampetra aepyperta) and Krueger and Olivereira (1999) in American eels (Anguilla rostrata) higher female percentages in the offspring when they grew at lower densities and vice versa. It was supposed that in these species, environmental sex determination (ESD) could be adaptive. The theory of Adaptive Significance declares that ESD is favoured when the environmental conditions preferentially benefit the reproductive success of one sex, male or female by favouring sexual size dimorphism (Charnov and Bull, 1977; St-Clair, 1998).

Distorted sex ratios in the genus Pelvicachromis gave an example for the influence of $\mathrm{pH}$ (Heiligenberg, 1965) as well as for Apistogramma the sex ratios were caused by $\mathrm{pH}$ reported by Römer and Beisenherz (1996).

Temperature dependent sex determination and differentiation is widely known to be a sex influencing factor which can lead to distorted sex ratios in the offspring of reptile and fish species. For various species of reptiles, egg incubation temperatures are responsible for distorted sex ratios, whereas for some fish species the temperatures during the alevin stages are pivotal (Tessema, 2001). 
The first discovery of incubation temperatures effecting the sex ratio of offspring was reported by Charnier (1966). She gained distorted sex ratios in rainbow lizard (Agama agama) when the hatchlings were incubated under different substrate conditions and temperatures. Later, Pieau (1972) confirmed the sex biasing influence of incubation temperature by systematic investigations on the European fresh water turtle (Emys orbicularis) and the Mediterranean tortoise (Testudo gracea).

Many more investigations have been undertaken since these in many other gonochoristic vertebrates such as turtles (Bull and Vogt, 1979; Yntema, 1979, Wood and Wood, 1982; Pieau et al., 1984), alligators (Bull, 1980; Viets et al., 1993, 1994; Pieau, 1996) and fish species (Conover and Kynard, 1981; Sullivan and Schultz, 1986; Conover and Heins, 1987a, b; Baroiller et al., 1993, 1995a,b; Struessmann et al., 1996; Abucay et al., 1999).

The most and extensively studied fish for sex determination is the Atlantic silverside (Menidia menidia) (Conover and Kynard, 1981; Conover, 1984; Conover and Heins, 1987a, b; Conover and van Voorhees, 1990; Conover et al., 1992). This species is an annual living fish of in the Atlantic Coast of the USA. They live only a very short time without intervention of generations. In the natural habitat of $M$. menidia the long growing season begins with the cold temperatures from $15{ }^{\circ} \mathrm{C}$ to $17{ }^{\circ} \mathrm{C}$, producing offspring which differentiate into females. However, the offspring that are produced later on in the breeding season, in the warmer temperatures, become males. A large body size is more important for the reproductive success of the females than of the males, as the progenies produced in the early breeding season have the advantage of a longer growing timeframe, whereas those produced in the later breeding season will have a shorter growing period, which consequently leads to a lower probability to become large. In M. menidia the sex determination system is believed to be based on sex determining main genes, the gene expression depends on the predominant water temperature. This dependence is variable to the genotype, which means that it can differ between populations and families within this species.

In cultured species that have bigger economical importance, only the Nile tilapia (Oreochromis niloticus) has been well investigated concerning sex determination mechanisms and the role played by the external factor "water temperature". In this species, male stocks for fatting are preferred because the females mature significantly earlier when they are contained in bins under high stocking densities. As they are characterized as 
mouth breeders they consequently deliver a decreased growth performance and an increase of gonads' growth (Tessema, 2001). The comprehensively investigated sex determining and sex differentiating mechanisms (Müller-Belecke and Hörstgen-Schwark, 1995; Baroiller et al., 1995b) in O. niloticus are supposed to be one of genetic main factors $(\mathrm{XX}-\mathrm{XY})$ along with additional autosomal genetic factors that interact with each, which in most cases determines the sex delivering balanced sex ratios (Wessels and Hörstgen-Schwark, 2007). The external factor "water temperature" is able to influence this relationship between the main and autosomal genetic factors resulting in distorted sex ratios that can have up to $100 \%$ males in temperature treated offspring.

In salmonids, sex determination and sex differentiation was generally believed to be under strict genetic control. Until today, only a few studies have been conducted concerning thermo-sensitivity of gonadal sex differentiation in early development stages in salmonids (van den Hurk and Lambert, 1982; Craig et al., 1996; Baroiller et al., 1999; Azuma et al., 2004).

Van den Hurk and Lambert (1982) demonstrated that high-temperature treatments (22 ${ }^{\circ} \mathrm{C}-29{ }^{\circ} \mathrm{C}$ for 10 min applied 17,31 or 57 days post fertilization) in rainbow trout did not influence the sex ratio. Baroiller et al. (1999) applied longer high temperature (19 ${ }^{\circ} \mathrm{C}$ ) treatments to genetically all-male and all-female populations during their entire hormonal-sensitive period without having any resultant effect on the respective sex ratios (unpublished data). In another Oncorhynchus species, Craig et al. (1996) observed an effect from temperature treatment (a shift of $8.3{ }^{\circ} \mathrm{C}-9.7^{\circ} \mathrm{C}$ to $10.4{ }^{\circ} \mathrm{C}-12.0^{\circ} \mathrm{C}$ ) during the incubation and alevin stages (40 to $86 \mathrm{dpf})$ in sockeye salmon $(O$. nerka) on the sex ratios with an increase in females in treated progenies. Azuma et al. (2004), however, found males in genetically all-female $O$. nerka, when the temperature treatment was raised from $9{ }^{\circ} \mathrm{C}$ to $18{ }^{\circ} \mathrm{C}$ for longer periods during embryonic and alevin stages.

Genetic sex determination (GSD), in general, is the acknowledged system of sex determination in rainbow trout $(O$. mykiss) with female homogamety ( $९ \mathrm{XX}-\lesssim \mathrm{XY})$ as well as in most other salmonids (Devlin and Nagahama, 2002). Quillet et al. (2002), however, found unexpected males in mitotic gynogenetic families of rainbow trout similar to observations in Nile tilapia (Oreochromis niloticus) (Mair et al., 1991; Müller-Belecke and Hörstgen-Schwark, 1995) and common carp (Cyprinus carpio) (Komen et al. 1992a, b; 1995) and suggested a similar sex determination mechanism as proposed in carp which gives evidence for the existence of a mutation (termed mas-1) that induces 
maleness in all-female progenies. Temperature conditions may have variable effects on sex differentiation depending on time of application, intensity of temperature and the genetic background of rainbow trout spawners.

Van den Hurk and Slof (1981) widely investigated the morphology of gonadal sex differentiation in rainbow trout (Table 2). The authors observed that gonadal sex differentiation starts between 45 and 55 days post fertilization when eggs were incubated at 11.5 ${ }^{\circ} \mathrm{C} \pm 0.5{ }^{\circ} \mathrm{C}$ and reared after hatching at $13{ }^{\circ} \mathrm{C} \pm 0.5{ }^{\circ} \mathrm{C}$ (approximately 600 degree days minimum). At the onset of gonadal differentiation testes are thin massive structures with the first differences between testis and ovaries not visible histologically before 50 days post fertilization.

Table 2: Ovarian development of rainbow trout from 50 to 250 days post fertilization (van den Hurk and Slof, 1981)

\begin{tabular}{|c|c|c|c|c|c|}
\hline Day & $\begin{array}{l}\text { Mean body } \\
\text { weight }(\mathrm{g})\end{array}$ & $\begin{array}{l}\text { Mean gonad } \\
\text { weight }(\mathrm{mg})\end{array}$ & $\begin{array}{c}\text { Mean GSI } \\
\left(\%{ }_{00}\right)\end{array}$ & $\begin{array}{c}\text { Max oocyte } \\
\text { diameter }(\mu \mathrm{m})\end{array}$ & Sex \\
\hline 50 & $0.20 \pm 0.05$ & $0.006 \pm 0.002$ & $0.03 \pm 0.01$ & -- & $\begin{array}{r}\text { not differ- } \\
\text { entiated }\end{array}$ \\
\hline 100 & $0.83 \pm 0.10$ & $0.74 \pm 0.05$ & $0.92 \pm 0.24$ & -- & \multirow{7}{*}{ Males } \\
\hline 150 & $1.68 \pm 0.25$ & $1.68 \pm 2.25$ & $0.41 \pm 0.10$ & -- & \\
\hline 200 & $5.14 \pm 2.36$ & $2.56 \pm 1.42$ & $0.50 \pm 0.68$ & -- & \\
\hline 250 & $17.14 \pm 8.75$ & $9.49 \pm 3.50$ & $0.58 \pm 0.08$ & -- & \\
\hline 300 & $43.11 \pm 12.99$ & $14.59 \pm 6.02$ & $0.34 \pm 0.07$ & -- & \\
\hline 350 & $85.58 \pm 19.63$ & $23.81 \pm 7.08$ & $0.28 \pm 0.06$ & -- & \\
\hline 400 & $102.60 \pm 13.40$ & $37.00 \pm 11.50$ & $0.37 \pm 0.41$ & -- & \\
\hline 100 & $0.92 \pm 0.18$ & $1.20 \pm 0.13$ & $1.35 \pm 0.34$ & 39 & \multirow{7}{*}{ Females } \\
\hline 150 & $3.10 \pm 0.45$ & $3.68 \pm 0.74$ & $1.20 \pm 0.11$ & 65 & \\
\hline 200 & $5.78 \pm 2.65$ & $14.23 \pm 12.02$ & $2.47 \pm 1.64$ & 124 & \\
\hline 250 & $17.71 \pm 6.50$ & $18.65 \pm 10.39$ & $1.38 \pm 0.50$ & 160 & \\
\hline 300 & $45.09 \pm 9.30$ & $46.82 \pm 11.67$ & $1.04 \pm 0.17$ & 200 & \\
\hline 350 & $90.40 \pm 23.06$ & $80.57 \pm 23.81$ & $0.89 \pm 0.08$ & 250 & \\
\hline 400 & $103.40 \pm 19.90$ & $114.90 \pm 47.50$ & $0.98 \pm 0.28$ & 340 & \\
\hline
\end{tabular}

At the beginning of sex differentiation testis are well-vascularized, with blood capillaries surrounding each spermatogonial cyst. The testicular weight increases from $6 \mu \mathrm{g} \pm$ $2 \mu \mathrm{g}$ at the beginning of testis formation to $37.0 \mathrm{mg} \pm 11.5 \mathrm{mg}$ at 400 days post fertilization. The mean gonadosomatic index (GSI: (total gonad weight/body weight - total gonad weight)*1000) at 50 days post fertilization is $0.003 \%$ and from $100-400$ days post fertilization the development of the testis is characterized by a very high increase of the 
number of cyst containing spermatogonia so that the GSI varies between $0.03 \%$ to $0.05 \%$.

The ovaries which are oval and yellowish-red, are structured histologically by a lamellar at the beginning of the development and have up to 8 germ cells group-wise. The mean GSI of females is $0.003 \%$ and increases up to $0.1 \%$ from 100 to 400 days post fertilization.

Padoa (1939) and Takashima et al. (1980) argued that sex differentiation takes place soon after the complete resorption of the yolk sac during the first feeding period dating 2 month post fertilization. Lebrun et al. (1982) observed that gonads remain undifferentiated up to 4 weeks post hatching at a temperature of $10^{\circ} \mathrm{C}-11^{\circ} \mathrm{C}$ (Figure 3 ).

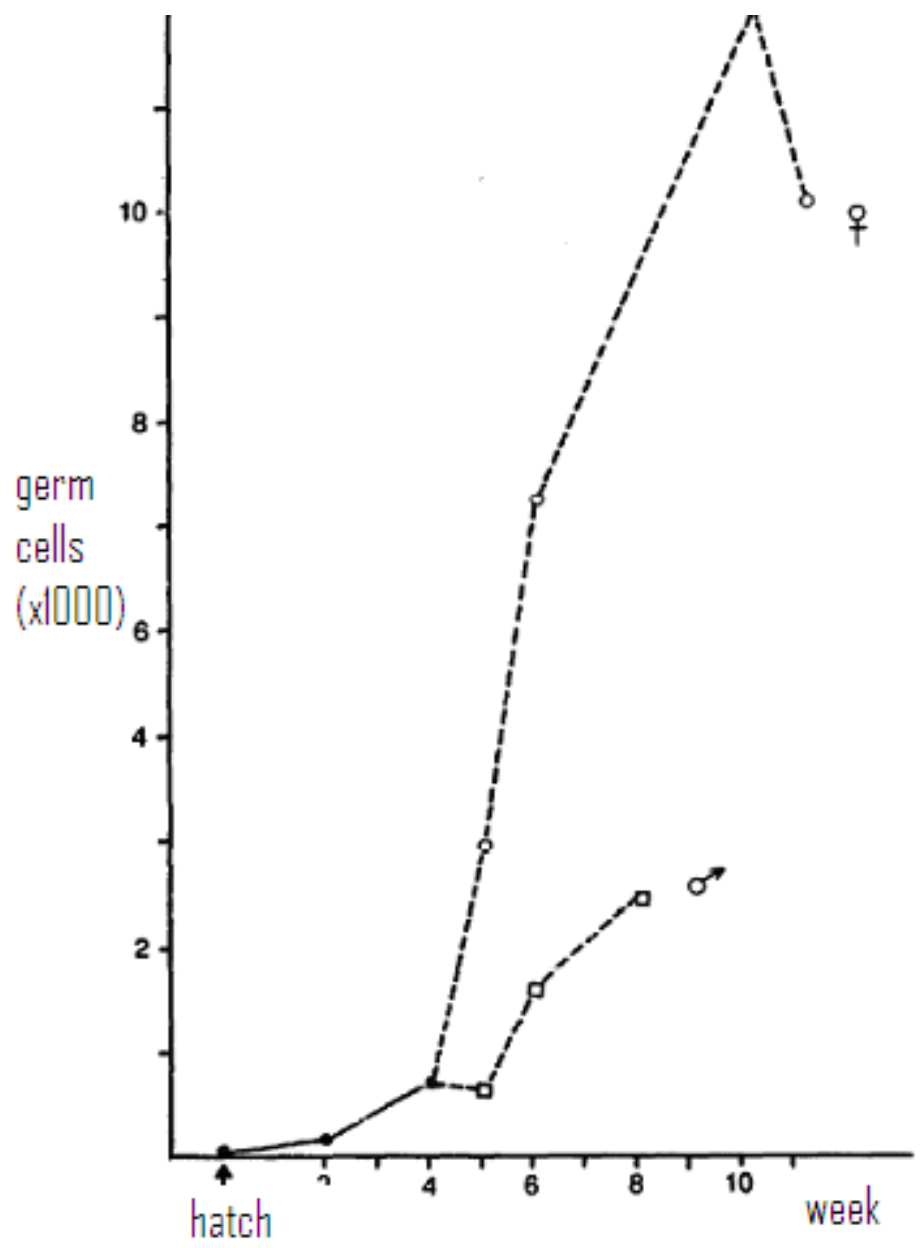

Figure 3: Changes in the total number of germ cells (in 1000) in the gonads of rainbow trout embryos during 11 weeks after hatching at a rearing temperature of $10{ }^{\circ} \mathrm{C}-11{ }^{\circ} \mathrm{C}$ (Billard, 1992; after Lebrun et al., 1982);

$=$ undifferentiated gonads. 
The authors stated that at 35 days post hatching some enlargements of the anterior part of the gonad occur, whereas at 42 days post hatching the first signs of lamellar structure of the gonads, typically for ovaries, were identified.

The formation of lamellae and completion of the structural development of the ovary occurs between 12 to 16 weeks post hatching (Upadhyay, 1977). Lebrun et al. (1982) reported changes in the number of germ cells (Figure 4) in the gonads. Soon after hatching when the average number of germ cells is low (around 50 in both gonads) the number increases to 2000 at 5 weeks post hatching. After 5 weeks post hatching, meiosis starts with a sharp increase in the number of germ cells up to 11.000 at 10 weeks post hatching. At this early stage of development soon after hatching sex differentiation appears labile and sex inversion can easily be obtained by external factors (Jalabert et al., 1975; Hunter and Donaldson, 1983). 


\section{Scope of the thesis}

The scope of this thesis was the evaluation of an alternative to the usage of hormonal treatment to produce neo-males in order to obtain all female rainbow trout offspring. For this reason the applicability of temperature treatment on rainbow trout progenies originating from different families, within and between different rainbow trout broodstocks, were studied. Thereby, changes in the sex ratio of temperature treated progenies as well as the ascertaining of the genetic background of thermo-sensitivity to sex differentiation were investigated.

In chapter 2, the effect of an elevated temperature of $18{ }^{\circ} \mathrm{C}$ for 30 days (starting on day 42 post fertilization) on sex ratios in progenies of six different rainbow trout broodstocks was analysed. Furthermore the sex ratios of repeated matings as well as the effect of mating partners on sex ratio was analysed. Each mating experiment was run with its own treatment group. The water temperature was kept at $18{ }^{\circ} \mathrm{C}$ for 30 days starting two weeks post hatching for treatment groups and the corresponding full sib control groups were kept continuously at $12{ }^{\circ} \mathrm{C}$ until sexing.

A selection experiment to alter the proportion of females over one generation of 3 years in rainbow trout was conducted in chapter 3 . Therefore, a base population including sex ratios and survival rates after temperature treatment of 95 temperature treated groups and their corresponding full sib control groups was created. For the high line with increased female proportion and for the low line with decreased female proportion in temperature treated offspring 6 families best available were selected for each of the two lines in order to generate the realized selection differentials. In Generation 1, 18 matings in the high line and 14 matings in the low line were conducted in order to determine the realized response to selection in both lines as well as to estimate the realized heritability for each line and for both lines together. Also a meiotic gynogenesis with a following temperature treatment was conducted in order to evaluate the possibility of producing functional males.

The general discussion and comparison of all results in the underlying experiment is held in chapter 4. 


\section{Chapter 2}

\section{Effect of rearing temperatures post hatching on sex ratios of rainbow trout (Oncorhynchus mykiss) populations}

Andreas Magerhans, Andreas Müller-Belecke, Gabriele Hörstgen-Schwark

Institute of Animal Husbandry and Genetics,

Albrecht-Thaer-Weg 3, D 37075 Göttingen, Germany

Aquaculture 294 (2009): 25 - 29 


\begin{abstract}
A comprehensive experiment was carried out to study the effect of an elevated temperature of $18{ }^{\circ} \mathrm{C}$ for 30 days (starting on day 42 post fertilization) on sex ratios in progenies of six different (I, II, III, IV, V and VI) rainbow trout broodstocks of the Experimental Trout Farm Relliehausen (University of Goettingen, Germany). Further, the repeatability of the obtained results and the effects of mating partners on temperature responsiveness were examined. In total about 7000 temperature-treated $\left(18{ }^{\circ} \mathrm{C}\right)$ fish and their corresponding 7000 full sibs kept at $12{ }^{\circ} \mathrm{C}$ were sexed. In general, the mean survival rates after temperature treatment of $18^{\circ} \mathrm{C}$ did not differ significantly from the corresponding values of the full sibs kept at $12{ }^{\circ} \mathrm{C}$. Significant differences to $18{ }^{\circ} \mathrm{C}$ temperature responsiveness were observed between the progenies of the six broodstock populations. Broodstock population II showed the highest mean female percentage of $60.6 \%$ of the temperature-treated progenies, while population III showed the lowest mean female percentage of $36.0 \%$. Single pair matings within four (I, III, V and VI) populations were repeated and the percentage of females in the $18{ }^{\circ} \mathrm{C}$ - treated replicated spawns differed only by $0.4 \%$ to $5.8 \%$. In addition, paternal and maternal half sibs showed that the sensitivity of sex ratios to temperature treatment varied between breeding pairs. Both parents, male and female, seem to contribute to the different sex ratios after treatment. It was concluded that a sensitivity of sex-differentiation to temperature treatments seems to exist in rainbow trout depending on the genotype and the applied temperature treatment.
\end{abstract}

Keywords: Oncorhynchus mykiss, rainbow trout, thermo-sensitivity, genotypetemperature-interactions

\title{
1. Introduction
}

Genetic sex determination (GSD), in general, is the acknowledged system of sex determination in rainbow trout (Oncorhynchus mykiss) with female homogamety ( $\odot \mathrm{XX}$ ${ }^{7} \mathrm{XY}$ ) as in most other salmonids (Devlin and Nagahama, 2002). In species with an evident chromosome system like the rainbow trout, sex determination of an individual takes place during egg fertilization as has been demonstrated in previous studies for genetic sex control approaches by induced gynogenesis (for example Chourrout (1984), Chourrout and Quillet (1982), Quillet et al. (2002)) and sex reversal experiments by hormonal treatment (for example Hunter and Donaldson, 1983). Sex differentiation, the process that goes from an undifferentiated gonad to a differentiated gonad, testis or ovary, occurs later. Recent studies in Oncorhynchus and Oreochromis species have 
shown that under some rearing conditions environmental factors (such as temperature) may modify the phenotypic sex of an individual and consequently, alter the sex ratios of the offspring. In Oncorhynchus nerka, Craig et al. (1996) observed an effect of temperature treatment (a shift of $8.3{ }^{\circ} \mathrm{C}-9.7{ }^{\circ} \mathrm{C}$ to $10.4{ }^{\circ} \mathrm{C}-12.0{ }^{\circ} \mathrm{C}$ ) during the incubation and alevin stage ( 40 to $86 \mathrm{dpf}$ ) of sockeye salmon on sex ratios by an increase of females in treated progenies. Azuma et al. (2004), however, found males in genetically all-female O. nerka, when the temperature treatment was raised from $9{ }^{\circ} \mathrm{C}$ to $18{ }^{\circ} \mathrm{C}$ for longer periods during embryonic and alevin stages. In contrast, van den Hurk and Lambert (1982) demonstrated that high-temperature treatments $\left(22^{\circ} \mathrm{C}-29^{\circ} \mathrm{C}\right.$ for $10 \mathrm{~min}$ applied 17,31 or 57 days post fertilization) in rainbow trout did not affect the sex ratio. Baroiller et al. (1999) applied longer high temperature $\left(19^{\circ} \mathrm{C}\right)$ treatments to genetically all-male and all-female rainbow trout populations during their entire hormonal-sensitive period without any effect on the respective sex ratios (unpublished data). But temperature conditions may have variable effects on sex differentiation depending on time of application, intensity of temperature and the genetic background of spawners as evidenced from studies in Oreochromis species (for example Tessema et al., 2006). Therefore a comprehensive experiment was carried out to study in more detail the effect of two different water temperatures on sex ratios in different rainbow trout populations during early alevin stage.

\section{Materials and methods}

Individually tagged spawners from six autumn spawning broodstocks of rainbow trout kept at the Experimental Trout Farm Relliehausen (University of Goettingen, Germany) were used as a breeding base. These broodstocks were kept as closed populations with pedigree mating. Each broodstock consisted of a minimum of 300 spawners which have been used in previous research (Komrakova, 2006). In the 2005/2006 breeding season, single pair matings within these six different rainbow trout broodstocks were conducted for the evaluation of thermo-sensitivity on gonadal sex differentiation. In the 2006/2007 breeding season repeated single pair matings were conducted and also half sib progenies were produced by mating of a male spawner to different female spawners and vice versa. The broodstocks that were used were kept in ponds with a final stocking density of $10 \mathrm{~kg} / \mathrm{m}^{3}$ (water temperature $\min 2{ }^{\circ} \mathrm{C}$ in winter and max $16{ }^{\circ} \mathrm{C}$ in summer, $\mathrm{O}_{2}>10$ $\mathrm{mg} / \mathrm{l}, \mathrm{pH} 6.5-8.0, \mathrm{NH}_{3}<0.01 \mathrm{mg} / \mathrm{l}, \mathrm{NO}_{2}<0.02 \mathrm{mg} / \mathrm{l}$ and $\left.\mathrm{NO}_{3}<10.0 \mathrm{mg} / \mathrm{l}\right)$. The spawners were given standard trout pellets two times each day (Trouvit F-8 Pro Aqua Repro, 
crude protein $46 \%$, crude fat $16 \%$ ). In contrast, the progenies were hatched and reared indoors using well water with a constant water temperature of $12{ }^{\circ} \mathrm{C} \pm 0.5^{\circ} \mathrm{C}$. Fertilized eggs of experimental progenies and hatched alevins were kept in Zuger glasses with a water temperature of $12{ }^{\circ} \mathrm{C} \pm 0.5^{\circ} \mathrm{C}$ till day 42 post fertilization (dpf) when temperature treatments started for 30 days. According to van den Hurk and Slof (1981), gonadal sex differentiation in rainbow trout starts between day 45 and day 55 after fertilization when eggs are kept at a water temperature of $11.5{ }^{\circ} \mathrm{C} \pm 0.5^{\circ} \mathrm{C}$. This corresponds to the timeframe of hormonal sex reversal in rainbow trout (Azuma et al., 2004).

In preliminary experiments, different temperature regimes were tested: further $12{ }^{\circ} \mathrm{C}$ or $16{ }^{\circ} \mathrm{C}, 18{ }^{\circ} \mathrm{C}$ and $20^{\circ} \mathrm{C}$ for 30 days starting at $42 \mathrm{dpf}$, when two thirds of the yolk sac of the fry was absorbed. At $12{ }^{\circ} \mathrm{C}$, none of the populations showed sex ratios that differed significantly from a 1:1 distribution, while several showed significant changes in sex ratios at $18{ }^{\circ} \mathrm{C}$ and $20^{\circ} \mathrm{C}$. The mortality of the fry kept at $20^{\circ} \mathrm{C}$ for 30 days was on average significantly higher than in the corresponding full sib groups kept at $12{ }^{\circ} \mathrm{C}$. As survival rates after $18{ }^{\circ} \mathrm{C}$ treatment were comparable and not significantly different from the ones of the corresponding full sib groups kept at $12{ }^{\circ} \mathrm{C}$, the $18{ }^{\circ} \mathrm{C}$ treatment was favoured as the next highest temperature. Thus, for the present investigations, temperature treatment of $18{ }^{\circ} \mathrm{C}$ for 30 days was used starting at $42 \mathrm{dpf}$. At that time, alevins were counted and each full sib progeny was separated into a treatment group kept at $18{ }^{\circ} \mathrm{C}$ and a corresponding full sib group kept at $12{ }^{\circ} \mathrm{C}$ (in the following refer to as control), each consisted of 300 fish $\left(\mathrm{n}_{1}\right)$. Temperature treatment was carried out in two semiclosed recirculation systems, each with 1000-1 volume and with a separate temperature regulation (thermo-regulator $3000 \mathrm{~W}$ ), bio filter and three compartments (each 300-1 volume with air blower 44 1/min). In each compartment, four net cages (25-1 baskets) were installed and in each net cage one full sib progeny was kept. The thermo-regulators did not exceed a maximum deviation of $0.2{ }^{\circ} \mathrm{C}$ to guarantee the specific temperature of $18{ }^{\circ} \mathrm{C}$ required for the experimental batch. Water temperature was checked three times daily and all other water parameters were checked twice a week. Alevins were gradually acclimatized to $18{ }^{\circ} \mathrm{C}$ temperature at the onset of the treatment and to $12{ }^{\circ} \mathrm{C}$ at the end of the treatment period by a slow up and down regulation over a period of 48 hours in order to reduce fish losses. The corresponding full sib groups (control groups) were kept continuously at a temperature of $12{ }^{\circ} \mathrm{C}$ in Zuger glasses accordingly to the procedure developed for family testing at the experimental trout farm (Morkramer et al., 1985; Hörstgen-Schwark et al., 1986; Hörstgen-Schwark, 1993). Fry were fed at apparent sati- 
ety (Trouvit Pro Aqua Brut, crude protein 57\%, crude fat 15\%). At the end of the treatment, fry in treatment $\left(18{ }^{\circ} \mathrm{C}\right)$ and in corresponding full sib controls $\left(12{ }^{\circ} \mathrm{C}\right)$ were counted again $\left(n_{2}\right)$. The survival rates were determined as $\left(n_{2}: n_{1}\right) \times 100$. The groups were then standardized to 150 fish each and placed in cylindrical tanks (volume 801 each) which were incorporated in semi-closed recirculation systems of 35 tanks each. Each semi-closed recirculation system had a volume of $10 \mathrm{~m}^{3}$ (rearing and water regeneration unit) and was supplied with about $30 \mathrm{~m}^{3}$ of fresh well water per day. The water temperature was constant with $12{ }^{\circ} \mathrm{C} \pm 0.2{ }^{\circ} \mathrm{C}$. At five months post fertilization, treatment $\left(18{ }^{\circ} \mathrm{C}\right)$ and corresponding control groups $\left(12{ }^{\circ} \mathrm{C}\right)$ started being fed three times daily (Trouvit Select 1P, crude protein $46 \%$, crude fat $15 \%$ ). At nine months post fertilization when the fish reached a weight of approximately $30 \mathrm{~g}$, fish were subjected to sexing. The water parameters in the trout breeding facilities, measured during the experimental period, were within the following range: $\mathrm{O}_{2}>7 \mathrm{mg} / \mathrm{l} ; \mathrm{pH}$ 6.5-7.5, $\mathrm{NH}_{3}<0.001$ $\mathrm{mg} / \mathrm{l}, \mathrm{NO}_{2}<0.005 \mathrm{mg} / \mathrm{l}$ and $\mathrm{NO}_{3}<5.0 \mathrm{mg} / \mathrm{l}$. Before sexing started, a random sample of 10 fish from each full sib group kept at $12{ }^{\circ} \mathrm{C}$ was separated and reared until sexual maturity so that they could become potential breeders of the next generation. All other fish were killed for sexing with an overdose of anaesthetic. Sexing was accomplished by examining the macroscopic anatomy of the gonads of each fish in the treatment $\left(18{ }^{\circ} \mathrm{C}\right)$ and corresponding control groups $\left(12^{\circ} \mathrm{C}\right)$ and, if necessary, by microscopic observation of gonad squashes (Guerrero and Shelton, 1974). For the analyses of significant differences in sex ratios and survival rates after temperature treatment between treatment (18 $\left.{ }^{\circ} \mathrm{C}\right)$ and corresponding control groups $\left(12{ }^{\circ} \mathrm{C}\right)$ the $\chi^{2}$, goodness-of-fit test $(P<0.05$, $0.01,0.001)$ of the statistical program SPSS Version 14 was used. Values for the deviation of the $12{ }^{\circ} \mathrm{C}$ control group's sex ratio from 1:1 distribution were also based on the $\chi^{2}$ - test procedure.

\section{Results}

Table 1 gives an overview of mean survival rates and sex ratios weighted by the number of sexed fish per family within the six populations. The number of families within populations differed according to the availability of ripe female spawners at the given time of temperature treatments in the course of the experiments in the 2005/2006 season. In general, survival rates of treatment groups $\left(18{ }^{\circ} \mathrm{C}\right)$ were significantly higher or at least comparable to corresponding full sib groups $\left(12{ }^{\circ} \mathrm{C}\right)$. The sex ratios in the full sib groups kept at $12{ }^{\circ} \mathrm{C}$ did not deviate significantly from $1: 1$ in any population as shown 
by $\chi^{2}$ - values $(<3.84)$. In four (I, II, IV, VI) of the six populations significantly higher mean percentages of females were observed in the treated groups $(57.5 \%-60.6 \%)$ than in the corresponding controls $(48.8 \%-51.2 \%)$, whereas in population III a significantly lower mean percentage of females was found in the treated groups $(36.0 \%)$ than in the corresponding controls $(50.5 \%)$. In population $\mathrm{V}$, the mean female percentage of treatment and full sib groups did not differ significantly from each other. Over all populations, the lowest percentage of females in a treatment group was observed in population III $(32.1 \%)$ and the highest number of females was found in population II (69.4\%). The percentage of temperature treated $\left(18{ }^{\circ} \mathrm{C}\right)$ families within populations which showed significantly different sex ratios from the controls $\left(12{ }^{\circ} \mathrm{C}\right.$ ) varied from $0 \%$ (population V) to $17 \%$ (population IV), 25\% (population I), 27\% (population VI), 29\% (population II) up to $80 \%$ (population III).

Repeatability of the response of sex ratios to temperature treatment of $18{ }^{\circ} \mathrm{C}$ for 30 days was investigated by testing progenies produced from successive spawnings of breeding pairs in the following year (Table 2). The two repeated spawns of all matings were compared with each other and none of the sex ratios in the first and second spawn within the $18{ }^{\circ} \mathrm{C}$ treatments and the corresponding control groups were significantly different from each other $(P<0.05)$. The percentage of females in the $18{ }^{\circ} \mathrm{C}$ treated replicated spawns varied only by $0.4 \%$ to $5.8 \%$. Survival rates of $18{ }^{\circ} \mathrm{C}$ temperature treated groups were in general significantly higher or at least comparable to the survival rates of the corresponding groups kept at $12{ }^{\circ} \mathrm{C}$. The mating ${ }^{\lambda} 5 \times q 15$ showed significantly lower female percentages $(34.5 \%, P<0.01 ; 38.2 \%, P<0.05)$ in the treatment groups $\left(18{ }^{\circ} \mathrm{C}\right)$ of repeated spawns compared to the corresponding full sib $\left(12{ }^{\circ} \mathrm{C}\right)$ values $(55.1 \%$ and $53.5 \%)$. The other mating $\delta 6 \times \uparrow 16$ showed significantly higher female percentages $(61.4 \%, P<0.01 ; 67.2 \%, P<0.05)$ in the treatment groups $\left(18{ }^{\circ} \mathrm{C}\right)$ of repeated spawns compared to the corresponding values $(47.4 \%$ and $52.3 \%)$ of the full sibs $\left(12{ }^{\circ} \mathrm{C}\right)$.

Furthermore, the influence of male and female parents on the progeny sex ratios was studied by using paternal and maternal half sibs. Table 3 shows data from four different females each mated to three randomly selected males and also data from three males each mated to three randomly selected females. The results obtained showed that the sensitivity of sex ratios to temperature treatment could vary between breeding pairs. Maternal half sibs of female 14 (mated with male 34, 42 and 64 in Table 3) for example, were compared with each other and the sex ratios of two batches within $18{ }^{\circ} \mathrm{C}$ treatment were significantly different from each other (matings $q 14 \times \hat{\delta} 42$ and $q 14 \times \hat{\jmath} 64$, 
$P<0.05)$ with percentages of females differing by up to $18.1 \%$. In another example, maternal half sibs of female 30 (mated with males 29, 33 and 42 in Table 3), were compared with each other and the sex ratios of two batches $(q 30 \times \S 29, q 30 \times \AA 42, P<0.05)$ were significantly different from each other with percentages of females differing by up to $14.4 \%$, however, in the other direction (decrease of female percentages). Further, paternal half sibs of male 29 (mated with females 3, 4 and 80 in Table 3) were compared with each other and the sex ratio of two batches $(\lesssim 29 \times q 3, \precsim 29 \times q 80, P<0.05)$ were significantly different from each other with percentages of females differing by up to $17.9 \%$. Thus, both, males and females apparently contributed to the different sex ratios after temperature treatment.

\section{Discussion}

Until now, very few experiments were carried out to study the effect of water temperatures on sex ratios in rainbow trout. In these experiments (van den Hurk and Lambert, 1982; Baroiller et al., 1999), no effect of temperature on sex ratios have been found. These studies analysed different temperature regimes and considered relative small sample sizes and a limited breeding base compared to the present study. Here, progenies from single pair matings of spawners randomly selected from six different rainbow trout broodstocks kept at the Experimental Trout Farm Relliehausen were studied for thermosensitivity of their sex ratios. The temperature treatment applied $\left(18{ }^{\circ} \mathrm{C}\right)$ was the highest one which did not cause significantly lower survival rates in experimental groups than in the corresponding full sib controls kept at $12{ }^{\circ} \mathrm{C}$. The results of this study showed that differences between populations and families within populations exist with regard to temperature sensitivity in the range of no (population V) to significantly higher (populations I, II, IV and VI) or significantly lower (population III) percentages of females. The highest deviation found in female percentage was $\pm 20 \%$ compared to corresponding control groups (Table 1).

In another Oncorhynchus species, the sockeye salmon (O. nerka), Azuma et al. (2004) showed that sex reversal from genetic females to functional males is possible by a temperature treatment of $18{ }^{\circ} \mathrm{C}$ (42 to $151 \mathrm{dpf}$ ) compared to $9{ }^{\circ} \mathrm{C}$ for controls. Such a sex reversal could have occurred in population III of the present experiment as a similar temperature and beginning of treatment were used. Interestingly, Komrakowa (2006) found that variant A of sex marker OmyP9 RsaI (Iturra et al., 2001) was present in this 
population and almost exclusively found in males. However, this variant A was also found in populations I, II and VI.

As Azuma et al. (2004) worked with an all-female population, the authors could not prove a sex reversal to females by elevated temperatures. Craig et al. (1996), however, found strongly female-biased sex ratios (62\% to $84 \%$ female) in different populations and population crosses of sockeye salmon when eggs were exposed to higher temperatures $\left(10.4{ }^{\circ} \mathrm{C}-12.0{ }^{\circ} \mathrm{C}\right.$; control: $\left.8.3{ }^{\circ} \mathrm{C}-9.7{ }^{\circ} \mathrm{C}\right)$ during embryonic development (starting at $360 \mathrm{dpf}$ ). These results of Craig et al. (1996) showed that, depending on the genetic background of the sockeye salmon population, temperature manipulation during incubation and hatching phase could alter the sex ratio. This is similar to the results in the present study which also showed female biased sex ratios in progenies of different broodstocks when they were exposed to higher temperatures post hatching. Temperature regime, however, varied between the studies as did the range of distortion in female percentages $(20 \%$ in this study versus $28 \%$ of females compared to controls in Craig et al., 1996). This implies that temperature is generally able to increase or decrease the proportion of females. In both studies (Craig et al., 1996 and the present study), it was proved that the sex ratios in temperature-treated progenies could not be attributed to differential higher mortality of females or males. In the present study, survival rates in treatment groups $\left(18^{\circ} \mathrm{C}\right)$ were often significantly higher than in the corresponding full sib control groups $\left(12{ }^{\circ} \mathrm{C}\right)$. It cannot be excluded that there might have been an effect of rearing tanks on survival rates, because tanks were different during temperature treatment for both groups due to limited space in the hatchery. Both groups, however, were reared in water of the same source with comparable water quality parameters except temperature. All in all, the important point is that higher mortality of one sex did not play a decisive role in the $18{ }^{\circ} \mathrm{C}$ treatment groups.

Until today, there is also no information available about the repeatability of the response of sex ratios to temperature treatments in rainbow trout. High repeatability of the response of sex ratios to temperature treatments was only proven in tilapia (O. niloticus) (Tessema et al., 2006). Tessema et al. (2006) showed that replicated $36{ }^{\circ} \mathrm{C}$ - treated spawns varied only by a range of $1.7 \%$ to $6.2 \%$. In the present study a similar repeatability was observed with a comparable narrow range of female biased sex ratios $(0.4 \%$ to $5.8 \%$, Table 2). The proven repeatability in successive matings, for example $\lesssim 5 \times q 15$ and $\delta \times+16$ which differed significantly $(P<0.05)$ from the corresponding control groups may be an indication for a genetic background of the sensitivity of temperature 
treatment on sex differentiating mechanisms as was proved for tilapia (Wessels and Hörstgen-Schwark, 2007).

Further, the present study gives evidence that both, males and females, contributed to the different sex ratios after temperature treatment. This result is consistent with the findings of Tessema et al. (2006) in tilapia. As can been seen in Table 3, depending on the maternal mating partner male 29 was mated to, paternal half sibs showed significantly different sex ratios $(P<0.05)$ with female percentages from $44 \%\left(\delta^{\Uparrow} 29 \times \bigcirc 3\right)$ to $62 \%$ (ふ29× 980 ). Significantly different sex ratios with female percentages from $48.8 \%$ $\left(q 14 \times \delta^{\lambda} 64\right)$ to $66.9 \%\left(q 14 \times{ }^{\lambda} 42, P<0.01\right)$ within the $18{ }^{\circ} \mathrm{C}$ temperature treatment were also observed for maternal half sibs of female 14 mated with males 64 and 42 . These examples showed a clear paternal and maternal influence on sex ratios after temperature treatment $\left(18^{\circ} \mathrm{C}\right)$.

All in all, the results obtained suggest that rainbow trout is a thermo-sensitive species and temperature can affect gonadal sex differentiation of the individuals during the early development stages. Currently, all female populations in rainbow trout (for large-size production $>1.2 \mathrm{~kg}$ body weight) are sired by neo-males which are obtained through hormonal treatment. Due to the growing concerns for food security, finding a sex control alternative based on consumer and environmentally friendly methods is a major challenge for trout production. An ongoing experiment will verify if it is possible to increase temperature sensitivity by selection. Alternatively, gynogenesis in combination with a following temperature treatment $\left(18{ }^{\circ} \mathrm{C}\right.$ for 30 days $)$ will be investigated with progenies of families of population III in order to get more information on functional males by temperature treatment.

\section{Acknowledgement}

The authors want to express their gratitude to Mr. Daniel Kaffke for his excellent technical assistance. This work was supported by the BLE (Nr. 514-33.22/03HS037). The authors would like to thank the anonymous reviewers for their valuable comments. 
Table 1. Effects of temperature treatment $\left(18^{\circ} \mathrm{C}\right.$ for 30 days) on progeny sex ratios from randomly selected broodstock from six rainbow trout populations

\begin{tabular}{|c|c|c|c|c|c|c|c|c|c|c|}
\hline \multirow[b]{2}{*}{$\begin{array}{l}\text { Popu- } \\
\text { lation }\end{array}$} & \multirow[b]{2}{*}{$\begin{array}{l}\text { No. of } \\
\text { matings } 1\end{array}$} & \multicolumn{2}{|c|}{ Treatment $\left(18^{\circ} \mathrm{C}\right)$} & \multirow[b]{2}{*}{$\begin{array}{c}\text { Female } \\
\%\end{array}$} & \multirow[b]{2}{*}{$\begin{array}{c}\text { Min-Max } \\
\%\end{array}$} & \multicolumn{2}{|c|}{ Control $\left(12^{\circ} \mathrm{C}\right)$} & \multirow[b]{2}{*}{$\begin{array}{c}\text { Female } \\
\%\end{array}$} & \multirow[b]{2}{*}{$\begin{array}{c}\text { Min-Max } \\
\%\end{array}$} & \multirow[b]{2}{*}{$\chi^{2}$} \\
\hline & & $\begin{array}{c}\text { Survival }^{2} \\
\%\end{array}$ & $\begin{array}{c}\text { Sexed } \\
n\end{array}$ & & & $\begin{array}{c}\text { Survival }^{2} \\
\%\end{array}$ & $\begin{array}{c}\text { Sexed } \\
n\end{array}$ & & & \\
\hline I & 4 & 92.0 & 327 & $59.9^{\mathrm{a}}$ & $56.3-64.6$ & 92.7 & 340 & 51.2 & $50.6-51.9$ & 0.19 \\
\hline II & 7 & 82.8 & 599 & $60.6^{\mathrm{a}}$ & $54.5-69.4$ & 81.1 & 629 & 48.8 & $48.0-52.2$ & 0.36 \\
\hline III & 5 & $83.9^{\mathrm{a}}$ & 485 & $36.0^{\mathrm{a}}$ & $32.1-38.4$ & 77.0 & 461 & 50.5 & $47.7-53.3$ & 0.54 \\
\hline IV & 6 & $90.3^{\mathrm{a}}$ & 749 & $57.5^{\mathrm{a}}$ & $53.8-65.8$ & 85.8 & 500 & 49.1 & $46.7-53.8$ & 0.01 \\
\hline V & 6 & $94.7^{\mathrm{a}}$ & 612 & 51.5 & $37.9-55.5$ & 81.6 & 543 & 48.7 & $46.2-52.4$ & 0.36 \\
\hline VI & 11 & $84.1^{\mathrm{a}}$ & 1017 & $58.6^{\mathrm{a}}$ & $53.4-67.1$ & 78.4 & 1011 & 49.5 & $47.1-53.6$ & 0.12 \\
\hline
\end{tabular}

${ }^{1}$ Matings in treatment and in $12{ }^{\circ} \mathrm{C}$ full sib control group.

${ }^{2}$ Average survival rates of matings within populations calculated 72 days post fertilization.

${ }^{\text {a }}$ Significantly different from the corresponding $12^{\circ} \mathrm{C}$ full sib control group $(P<0.05)$.

$\chi^{2}=$ values for deviation of the corresponding $12{ }^{\circ} \mathrm{C}$ full sib control group's sex ratios from 1:1. 
Table 2. Effects of temperature treatment $\left(18^{\circ} \mathrm{C}\right.$ for 30 days $)$ on sex ratios of full sib progenies produced from repeated single pair matings within four different rainbow trout populations

\begin{tabular}{|c|c|c|c|c|c|c|c|c|c|}
\hline \multirow{3}{*}{ Population } & & & \multicolumn{3}{|c|}{ Treatment $\left(18^{\circ} \mathrm{C}\right)$} & \multicolumn{4}{|c|}{ Control $\left(12^{\circ} \mathrm{C}\right)$} \\
\hline & \multicolumn{2}{|c|}{ Mating $^{1}$} & Survival $^{2}$ & Sexed & Female & Survival $^{2}$ & Sexed & Female & $\chi^{2}$ \\
\hline & Male & Female & & $n$ & $\%$ & & $n$ & $\%$ & \\
\hline I & 1 & 11 & 93.2 & 118 & 60.2 & 92.5 & 84 & 51.2 & 0.48 \\
\hline $\mathrm{I}$ & 1 & 11 & $95.8^{\mathrm{a}}$ & 73 & 64.4 & 90.8 & 83 & 51.8 & 0.11 \\
\hline III & 4 & 14 & $68.3^{\mathrm{b}}$ & 114 & 36.8 & 55.0 & 112 & 42.9 & 2.29 \\
\hline III & 4 & 14 & $70.0^{\mathrm{b}}$ & 104 & 32.3 & 55.1 & 77 & 44.2 & 1.05 \\
\hline III & 5 & 15 & 73.3 & 87 & $34.5^{\mathrm{b}}$ & 66.7 & 78 & 55.1 & 0.82 \\
\hline III & 5 & 15 & $84.4^{\mathrm{b}}$ & 89 & $38.2^{\mathrm{a}}$ & 72.7 & 86 & 53.5 & 0.42 \\
\hline V & 2 & 12 & $98.3^{\mathrm{c}}$ & 130 & 53.1 & 88.3 & 87 & 48.3 & 0.10 \\
\hline V & 2 & 12 & $98.2^{\mathrm{c}}$ & 114 & 55.3 & 88.0 & 85 & 47.1 & 0.29 \\
\hline V & 3 & 13 & $94.0^{\mathrm{c}}$ & 91 & 53.8 & 72.7 & 102 & 44.1 & 1.41 \\
\hline V & 3 & 13 & $94.0^{\mathrm{c}}$ & 107 & 54.2 & 72.6 & 76 & 44.7 & 0.84 \\
\hline VI & 6 & 16 & $84.2^{\mathrm{c}}$ & 88 & $61.4^{\mathrm{b}}$ & 67.2 & 95 & 47.4 & 2.37 \\
\hline VI & 6 & 16 & 96.6 & 131 & $67.2^{\mathrm{a}}$ & 92.0 & 107 & 52.3 & 0.23 \\
\hline VI & 7 & 17 & $98.3^{\mathrm{c}}$ & 83 & 56.6 & 81.3 & 74 & 47.3 & 0.22 \\
\hline VI & 7 & 17 & 83.8 & 78 & 57.7 & 81.8 & 96 & 47.9 & 0.17 \\
\hline
\end{tabular}

${ }^{\mathrm{T}}$ Number of mating partner.

${ }^{2}$ Survival rate of progeny at the end of the temperature treatment, 72 days post fertilization.

a, b, c Significantly different from $12^{\circ} \mathrm{C}$ full sib control group $(P<0.05,0.01,0.001)$.

$\chi^{2}=$ values for deviation of the $12^{\circ} \mathrm{C}$ full sib control group's sex ratios from 1:1. 
Table 3. Effects of temperature treatment $\left(18^{\circ} \mathrm{C}\right.$ for 30 days $)$ on sex ratios of half sib progenies produced from single pair matings of individual fish of different rainbow trout populations

Treatment $\left(18^{\circ} \mathrm{C}\right) \quad$ Control $\left(12^{\circ} \mathrm{C}\right)$

Matings $^{1} \quad$ Survival $^{2}$ Sexed Female Survival $^{2}$ Sexed Female $\chi^{2}$

\begin{tabular}{lllllcccc} 
Female & Male & $\%$ & $n$ & $\%$ & $\%$ & $n$ & $\%$ & \\
\hline $14(\mathrm{III})$ & $34(\mathrm{II})$ & 96.5 & 123 & $58.5^{\mathrm{a}}$ & 96.8 & 117 & 45.3 & 1.03 \\
$14(\mathrm{III})$ & $42(\mathrm{VI})$ & 93.3 & 121 & $66.9^{\mathrm{b}}$ & 88.4 & 126 & 48.4 & 0.13 \\
$14(\mathrm{III})$ & $64(\mathrm{IV})$ & 82.7 & 128 & 48.8 & 81.7 & 111 & 45.9 & 0.73 \\
& & & & & & & & \\
$30(\mathrm{III})$ & $29(\mathrm{III})$ & 94.3 & 101 & $35.6^{\mathrm{a}}$ & 92.5 & 112 & 49.3 & 0.32 \\
$30(\mathrm{III})$ & $33(\mathrm{II})$ & $95.3^{\mathrm{c}}$ & 113 & 39.8 & 84.8 & 92 & 46.7 & 0.39 \\
$30(\mathrm{III})$ & $42(\mathrm{VI})$ & 91.3 & 104 & 50.0 & 90.5 & 124 & 47.6 & 0.30 \\
& & & & & & & & \\
$33(\mathrm{VI})$ & $33(\mathrm{II})$ & 93.3 & 122 & 55.7 & 91.5 & 117 & 51.3 & 0.08 \\
$33(\mathrm{VI})$ & $63(\mathrm{VI})$ & 81.3 & 106 & $65.1^{\mathrm{a}}$ & 81.0 & 127 & 48.8 & 0.07 \\
$33(\mathrm{VI})$ & 61 (II) & $83.7^{\mathrm{a}}$ & 90 & 48.9 & 76.3 & 124 & 47.6 & 0.29 \\
& & & & & & & & \\
$40(\mathrm{VI})$ & $27(\mathrm{III})$ & 90.3 & 119 & 59.7 & 88.0 & 116 & 51.7 & 0.14 \\
$40(\mathrm{VI})$ & $46(\mathrm{VI})$ & 93.7 & 127 & $62.2^{\mathrm{a}}$ & 90.7 & 131 & 47.3 & 0.37 \\
$40(\mathrm{VI})$ & $48(\mathrm{IV})$ & 87.3 & 105 & $61.9^{\mathrm{a}}$ & 88.9 & 110 & 49.1 & 0.04
\end{tabular}

Male Female

\begin{tabular}{lcccccccc}
\hline 29 (III) & 3 (VI) & $91.2^{\mathrm{a}}$ & 120 & 44.2 & 85.5 & 124 & 47.6 & 0.29 \\
29 (III) & 4 (II) & $93.0^{\mathrm{c}}$ & 131 & $61.1^{\mathrm{a}}$ & 79.0 & 120 & 49.2 & 0.03 \\
29 (III) & $80(\mathrm{II})$ & 90.5 & 132 & $62.1^{\mathrm{a}}$ & 87.6 & 106 & 49.1 & 0.04 \\
& & & & & & & & \\
$33(\mathrm{II})$ & $12(\mathrm{~V})$ & $96.2^{\mathrm{a}}$ & 117 & 41.9 & 92.0 & 108 & 51.9 & 0.15 \\
$33(\mathrm{II})$ & $56(\mathrm{III})$ & $94.8^{\mathrm{c}}$ & 109 & 41.3 & 76.5 & 94 & 51.2 & 0.04 \\
$33(\mathrm{II})$ & $80(\mathrm{II})$ & 94.5 & 84 & 63.1 & 90.7 & 121 & 47.5 & 0.41 \\
& & & & & & & & \\
$42(\mathrm{VI})$ & $3(\mathrm{VI})$ & $96.5^{\mathrm{a}}$ & 131 & $67.2^{\mathrm{a}}$ & 92.0 & 107 & 52.3 & 0.23 \\
$42(\mathrm{VI})$ & $47(\mathrm{II})$ & 92.9 & 114 & 64.0 & 90.3 & 88 & 51.1 & 0.05 \\
$42(\mathrm{VI})$ & $67(\mathrm{IV})$ & $89.0^{\mathrm{a}}$ & 135 & 52.6 & 83.8 & 139 & 49.6 & 0.07 \\
\hline
\end{tabular}

${ }^{1}$ Number of mating partner; population of spawner in brackets.

${ }^{2}$ Survival rates of progeny at the end of the temperature treatment,72 days post fertilization.

a, b, c Significantly different from full sib control group $(P<0.05,0.01,0.001)$.

$\chi^{2}=$ values for deviation of the full sib control group's sex ratios from 1:1. 
The obtained results in chapter 2 suggest that rainbow trout is a thermo-sensitive species and temperature can influence gonadal sex differentiation of the individuals during the early development stages. All female production in rainbow trout (for large-size production $>1.2 \mathrm{~kg}$ body weight) is currently achieved by siring neo-males, which are obtained through hormonal treatment, to normal females. The growing concerns for food security and for consumer- as well as environment friendly produced human food make it necessary to find a sex control alternative based on these aspects. This is the major challenge for large rainbow trout $(>1.2 \mathrm{~kg}$ ) production today.

The hopeful results of the thermo-treatment experiment presented in chapter 2 led to an ongoing selection experiment, which is described in detail in the following chapter. Therein, the possibility to alter the sex ratio in rainbow trout by means of temperature treatment and to increase "thermo- sensitivity" during sex differentiation by selection is presented. Alternatively, gynogenesis in combination with a following temperature treatment $\left(18{ }^{\circ} \mathrm{C}\right.$ for 30 days) was investigated with progenies of families of population III in order to get more information on functional males by temperature treatment. 


\section{Chapter 3}

\section{Selection experiments to alter the sex ratio in rainbow trout (Oncorhynchus mykiss) by means of temperature treatment}

Andreas Magerhans and Gabriele Hörstgen-Schwark

Institute of Animal Husbandry and Genetics,

Albrecht-Thaer-Weg 3, D-37075 Göttingen, Germany

Aquaculture 306 (2010): $63-67$ 


\section{Abstract}

A selection experiment in rainbow trout (Oncorhynchus mykiss) was initiated to verify if the proportion of females after temperature treatment could be significantly altered by selection. Rainbow trout spawners out of six populations were used to produce a diallel cross in which all populations were used as male as well as female parents. The 95 families of this breeding base were tested for their temperature sensitivity as follows. After an incubation period of 42 days, alevins of each family were subdivided into a treatment group and a full sib control group $\left(12^{\circ} \mathrm{C}\right)$, each consisting of 300 fish. Temperature treatments were carried out with $18{ }^{\circ} \mathrm{C}$ for 30 days. Each treatment and corresponding control group was raised separately until an age of 9 months post fertilisation. Then a random sample of 10 fingerlings out of each control group was kept for later selection decisions. All other fish from the treatment and control groups were sexed by microscopic inspection of gonad squashes. The families were ranked according to the percentage of females, and families with the highest $(n=6)$ and lowest percentage of females $(n=6)$ in their sex ratios after temperature treatment were selected to produce two divergent lines (high and low line). After one generation of selection the temperature treated groups in the high line showed a female percentage of 58\%, whereas the low line had an average female proportion of $44 \%$. The realized heritability was 0.63 in the high and 0.71 in the low line. This study provides the first evidence that the sex ratios in temperature treated groups of rainbow trout can be selected as a quantitative trait. Additionally, in the meiotic gynogenetic offspring derived from a female spawner, which showed low percentages of females after temperature treatment in previous matings, $16 \%$ males were observed in the temperature treated group. Thus, there seem to be two possible consumer- and environment-friendly ways to increase significantly the proportion of females in rainbow trout: directly via selection of families which show a high percentage of females in their sex ratios after temperature treatment to build up a corresponding temperature sensitive line or indirectly via neo-males derived from temperature treatments of gynogenetic offspring.

Keywords: Oncorhynchus mykiss, rainbow trout, selection experiment, genotypetemperature interaction, meiotic gynogenesis.

\section{Introduction}

The production of large rainbow trout (Oncorhynchus mykiss) over $1.2 \mathrm{~kg}$ body weight has become of a growing commercial interest in the world. The major bottleneck in this 
field is the early maturity of the male rainbow trout relative to female. Thus, all female rainbow trout stocks are preferred, which are currently produced by the use of neo-males in matings with normal females. The growing concerns for food security make the prevalent approach of producing neo-males via the oral application of testosterone to sexual indifferent fry less desirable. The finding of a sex control alternative based on a safe, consumer and environmentally friendly method is a major challenge for the production of all female populations (Azuma et al., 2004). Recent studies in Nile tilapia (Oreochromis niloticus) have shown that rearing temperature may modify the phenotypic sex of an individual and consequently alter the sex ratios of the offspring. This temperature sensitivity during the sexual undifferentiated phase has a genetic background (Baroiller et al., 2009).

In Oncorhynchus species, previous studies have also shown that under certain rearing conditions, environmental factors (such as temperature) may modify the phenotypic sex of an individual and consequently alter the sex ratios of the offspring. Azuma et al. (2004) found males in genetically all-female sockeye salmon (Oncorhynchus nerka), when the authors raised the temperature from $9{ }^{\circ} \mathrm{C}$ to $18{ }^{\circ} \mathrm{C}$ for longer periods during embryonic and alevin stages. Craig et al. (1996) observed an increase of females in temperature treated offspring also in sockeye salmon, when a temperature shift of $8.3{ }^{\circ} \mathrm{C}-9.7$ ${ }^{\circ} \mathrm{C}$ to $10.4{ }^{\circ} \mathrm{C}-12.0{ }^{\circ} \mathrm{C}$ was applied during incubation and alevin stage (40-86 dpf). Nagler et al. (2001) also reported that sex reversal in chinook salmon (Oncorhynchus tshawytcha) from the Columbia River could occur from an exposure to fluctuating temperatures. In rainbow trout, Magerhans et al. (2009) observed differences between and within populations with regard to thermal responsiveness of sex ratios, maternal and paternal effects on temperature dependent sex ratios, and nearly identical results of repeated matings, which are similar to observations in Nile tilapia (Baroiller et al., 1995; Tessema et al., 2006). In Nile tilapia, Wessels and Hörstgen-Schwark (2007) could show in a two generation selection experiment that thermo-sensitivity to sex differentiation is a heritable trait. Hence, in the present investigations with rainbow trout, the anticipated response to selection regarding sex ratios in temperature treated groups was tested in an up and down selection experiment.

\section{Materials and methods}

Rainbow trout spawners from six populations were used to produce a diallel cross, in which all populations were used as male as well as female parents. All spawners were 
kept in ponds at the Experimental Trout Farm Relliehausen (University of Göttingen, Germany) with a final stocking density of $10 \mathrm{~kg} / \mathrm{m}^{3}$ (water temperature $\min 2{ }^{\circ} \mathrm{C}$ in winter and $\max 16{ }^{\circ} \mathrm{C}$ in summer, $\mathrm{O}_{2}>8 \mathrm{mg} / \mathrm{l}, \mathrm{pH} 6.5-8.0, \mathrm{NH}_{3}<0.01 \mathrm{mg} / \mathrm{l}, \mathrm{NO}_{2}<0.01$ $\mathrm{mg} / \mathrm{l}$ and $\left.\mathrm{NO}_{3}<10.0 \mathrm{mg} / \mathrm{l}\right)$. The broodstock was given standard trout pellets twice per day (Trouvit F-8 Pro Aqua Repro, crude protein 46\%, crude fat 16\%). Single pair matings of individually tagged spawners were carried out to produce full sib families for temperature experiments. In contrast to the spawners used, produced progenies were hatched and reared indoors by the use of well water of constant quality and temperature of $12{ }^{\circ} \mathrm{C} \pm 0.3{ }^{\circ} \mathrm{C}$.

The 95 families which were used as a breeding base were tested for their temperature sensitivity in the following way. Fertilized eggs and hatched alevins were kept in Zuger glasses at a water temperature of $12{ }^{\circ} \mathrm{C} \pm 0.3{ }^{\circ} \mathrm{C}$ till day 42 post fertilization (dpf). At that time, alevins were counted and each progeny batch was separated into a treatment and a full sib control group, each consisting of 300 fish $\left(n_{1}\right)$. The temperature treatment was carried out according to the recommendations of Magerhans et al. (2009). The full sib control groups were kept at $12{ }^{\circ} \mathrm{C} \pm 0.3{ }^{\circ} \mathrm{C}$ water temperature whereas the treatment groups were subjected to a thermal treatment at $18{ }^{\circ} \mathrm{C}$ water temperature for 30 days. Temperature treatment was carried out in two semi-closed recirculation systems, each of 10001 volume with a separate temperature regulation (thermo-regulator $3000 \mathrm{~W}$ ), bio filter and three compartments (each 3001 volume with air blower 44 1/min). In each compartment four net cages (25 1) were installed, and in each net cage one full sib progeny was kept. The thermo-regulators did not exceed a maximum deviation of $0.2{ }^{\circ} \mathrm{C}$ to guarantee the specific temperature of $18{ }^{\circ} \mathrm{C}$ required for the experimental batch. Water temperature was checked three times daily and all other water parameters were checked twice a week. Alevins were gradually acclimatized to $18{ }^{\circ} \mathrm{C}$ temperature at the onset of the treatment and to $12{ }^{\circ} \mathrm{C}$ at the end of the treatment period by a slow up and down temperature regulation over a period of 48 hours in order to reduce fish losses. According to the procedure developed for family testing at the experimental trout farm (Morkramer et al., 1985; Hörstgen-Schwark et al., 1986; Hörstgen-Schwark, 1993) the corresponding full sib control groups were kept continuously at $12{ }^{\circ} \mathrm{C}$ in Zuger glasses. First feeding fry were given Trouvit Pro Aqua Brut diet (crude protein 57\%, crude fat $15 \%)$ to apparent satiety. After temperature treatment, fry in the treatment and in the corresponding full sib control groups were counted again $\left(\mathrm{n}_{2}\right)$ to determine the survival rates as $\left(\mathrm{n}_{2}: \mathrm{n}_{1}\right) \times 100$. Both groups were then standardized to 150 fish each and placed 
in cylindrical tanks (volume 801 each), which were incorporated in semi-closed recirculation systems of 35 tanks each. These systems were used and described in detail by Morkramer et al. (1985) and Hörstgen-Schwark (1993). Each semi-closed recirculation system had a volume of $10 \mathrm{~m}^{3}$ (rearing and water regeneration unit) and was supplied with about $30 \mathrm{~m}^{3}$ of fresh well water per day. The water temperature was constant at 12 ${ }^{\circ} \mathrm{C} \pm 0.2{ }^{\circ} \mathrm{C}$. Five months post fertilization, treatment and control groups were fed three times daily (Trouvit Select 1P, crude protein 46\%, crude fat 15\%). Nine months post fertilization, when the fish reached a weight of approximately $30 \mathrm{~g}$, they were subjected to sexing. The well water parameters in the trout breeding facilities, measured during the whole experimental period, were within the following range: $\mathrm{O}_{2}>8 \mathrm{mg} / \mathrm{l} ; \mathrm{pH}$ 6.5-7.5, $\mathrm{NH}_{3}<0.001 \mathrm{mg} / \mathrm{l}, \mathrm{NO}_{2}<0.005 \mathrm{mg} / \mathrm{l}$ and $\mathrm{NO}_{3}<5.0 \mathrm{mg} / \mathrm{l}$. Before sexing started, a random sample of 10 fish from each full sib control group was kept as putative breeders for the next generation. All other fish were killed by an overdose of anaesthetic. Sexing was accomplished by microscopic observation of gonad squashes (Guerrero and Shelton, 1974) of each fish in the treatment and in the corresponding full sib control groups.

The chi-square, goodness-of-fit test was applied for analysis of the sex ratios of the full sib control groups. For the verification of a normal distribution of sex ratios within each line and generation the Kolmogorov-Smirnov test was applied. For the analysis of differences in sex ratios and survival rates between treatment and control groups for significance the $\chi^{2}$, goodness-of-fit test $(P<0.05,0.01,0.001)$ of the statistical program SPSS Version 14 was used. Then families were ranked accordingly to the percentage of females and those with the highest $(n=6)$ and lowest $(n=6)$ percentage of females in their sex ratios after temperature treatment were selected to produce two divergent lines (high and low line). Similar to selection experiments in Nile tilapia to increase the proportion of males by temperature treatments (Wessels and Hörstgen-Schwark, 2007) means were weighted according to the number of offspring in each group before the selection differential and response to selection for the sex ratios in temperature treated groups were estimated.

The realized selection differentials $\left(S_{R}\right)$ showing the mean superiority of selected families (in \% females) were obtained for each line by the subtraction of the weighted average sex ratio of the base population (G0) from the weighted selected families' mean (data not shown). Standardized realized selection differentials $\left(S_{R}\right.$ in $\left.S D\right)$ were obtained by dividing the realized selection differential $\left(S_{R}\right)$ by the corresponding line's (population) standard deviation (SD) of the sex ratio in temperature treated groups. The realized 
response to selection $\left(\Delta \mathrm{G}_{\mathrm{R}}\right)$ was calculated for both lines separately by the subtraction of the weighted mean sex ratio of the first generation of selection (G1) from the breeding base $(\mathrm{G} 0)$. Realized selection responses in the first generation $\left(\Delta \mathrm{G}_{\mathrm{R}}\right)$ in relation to the applied selection $\left(\mathrm{S}_{\mathrm{R}}\right)$ were given by realized heritabilities $\left(\mathrm{h}_{\mathrm{R}}{ }^{2}\right)$ for the high and the low line according to Falconer and Mackay (1996).

Furthermore 10 fish were taken randomly out of a random sample of 12 different treatment and corresponding full sib control groups in G0 and raised group-wise in tanks under standardized conditions until 18 months post fertilization. The fish were then sexed and their body weights recorded.

Additionally, a meiotic gynogenesis was conducted with a female spawner showing low percentages of females in offspring after temperature treatment in previous matings. Meiotic gynogenesis was induced according to the method of Chourrout and Quillet (1982) and a haploid control was kept in order to verify the success of the induced gynogenesis. Gynogenetic offspring were divided into a treatment and a full sib control group and handled in the same way as the full sib progeny from single pair matings.

\section{Results}

Table 1 gives an overview on mean survival rates and sex ratios in the treatment and full sib control groups of the breeding base (G0) and in the high and the low line of the first generation of selection (G1). The numbers of families within the high $(n=18)$ and the low line $(n=14)$ in G1 differed according to the availability of ripe female spawners in the selection lines in the course of this experiment. In general, survival rates of treatment groups were significantly higher than for the corresponding full sib control groups indicating that the differences between sex ratios in treatment and corresponding full sib control groups cannot be attributed to higher mortality of one sex. The results of the Kolmogorov-Smirnov test showed that neither for the breeding base (G0) nor for the high or low line (G1) the female sex ratios' distribution differed significantly $(P<0.05)$ from normality. However, a few outliers were observed in each of both lines of G1: In the high line one family (5\% of the high line) with a female percentage of $72 \%$ and in the low line one family (7\% of the low line) with a female percentage of $32.5 \%$. These outliers observed in both lines (G1) might indicate potential QTL. The sex ratios in the control groups of G0 and G1 did not deviate significantly from 1:1 as shown by $\chi^{2}$ - values $(<3.84)$. In G0, no significantly $(P<0.05)$ higher mean percentage of females in the treatment group was observed $(51.9 \% \pm 8.9)$ than in the corresponding full sib control 
group $(49.3 \% \pm 3.1)$. After one generation of selection the mean percentage of females in the high line of G1 showed a significant increase up to $57.6 \%$ compared to $49.5 \%$ in the corresponding full sib control group. In the low line of G1 a significant decrease in mean female percentage was observed, down to $44.5 \%$ versus $49.6 \%$ in the corresponding full sib control groups. Both the high line and the low line of G1, showed mean female percentages in the treatment groups which differed significantly from the corresponding value in the base population G0.

In Table 2 the relevant parameters of the selection experiment have been summarized. Both lines were developed from the same breeding base which consisted of 95 families. The proportion of selected families in the high and the low line was identical $(6.3 \%)$. The realized selection differential $\left(\mathrm{S}_{\mathrm{R}}\right)$ of the high line (+9.0\% females) and the low line (-10.4\% females) were comparable. In terms of standard deviations, the standardized realized selection differentials $\left(S_{R}\right.$ in $\left.S D\right)$ reached values over 2 in both lines (high line +2.6; low line -2.2). Comparable results were also obtained for the realized response to selection in both lines (high line $\Delta \mathrm{G}_{\mathrm{R}}=+5.7 \%$; low line $\Delta \mathrm{G}_{\mathrm{R}}=-7.4 \%$ ) in the first generation of selection. In terms of standard deviation, the standardized realized response to selection $\left(\Delta \mathrm{G}_{\mathrm{R}}\right.$ in $\left.\mathrm{SD}\right)$ in the high line was 1.2 , somewhat lower than the low line with 1.7. The realized heritability $\left(\mathrm{h}_{\mathrm{R}}{ }^{2}\right)$ expressed as the ratio of the realized response to selection (high line $\Delta \mathrm{G}_{\mathrm{R}}=5.7 \%$ and low line $\Delta \mathrm{G}_{\mathrm{R}}=-7.4 \%$ ) and the realized selection differential (high line $\mathrm{S}_{\mathrm{R}}=9.0 \%$ and the low line $\mathrm{S}_{\mathrm{R}}=-10.4 \%$ ) was $\mathrm{h}_{\mathrm{R}}{ }^{2}=0.63$ in the high line and $\mathrm{h}_{\mathrm{R}}{ }^{2}=0.71$ in the low line, resulting in an average realized heritability of $\mathrm{h}_{\mathrm{R}}{ }^{2}=$ 0.67. Although an increase and decrease of female proportions in the treatment groups of the high and the low line could be observed in the first generation of selection, the mean sex ratios in all the controls of G0 and G1 were close to a female proportion of $50 \%$. The realized selection differentials of the corresponding control groups were $0.6 \%$ and $0 \%$ in the high and the low line respectively, thus no correlated response to selection could be observed regarding the proportion of females in the full sib control groups in the course of selection (Table 1).

With regard to body weights, the temperature treated fish and the fish of corresponding controls (in total 120 were temperature treated fish and 120 fish were of corresponding full sib controls) differed significantly from each other at the age of 18 months (t-test, $P$ $<0.01$ ). Temperature treated fish had a mean body weight of $286.8 \mathrm{~g} \pm 11.6$ whereas untreated full sib controls showed a mean body weight of only $276.4 \mathrm{~g} \pm 13$.8. Both groups showed a similar coefficient of variation $(\mathrm{CV})$ of $4 \%$ for body weight in temperature 
treated groups and 5\% in the corresponding full sib controls. Results of temperature treatment of the meiotic gynogenetic offspring revealed 16\% males (absolute: 85 females and 16 males) and 4\% males (absolute: 104 females and 4 males) in the corresponding full sib control group. All the haploid control alevins $(n=50)$ died, which generally indicated that the procedure of meiotic gynogenesis was conducted correctly.

\section{Discussion}

The main aim of the present experiment was to evaluate the possibility of altering the sex ratio in progenies of rainbow trout families through selection of thermo-sensitive families with unbalanced sex ratios in their temperature treated offspring. Due to the limited family rearing facilities of the trout farm Relliehausen and because of the long generation interval of rainbow trout it was only possible to carry out a one generation selection experiment till now. It was possible to select for increased (high line) as well as for decreased female proportions (low line) in the selection lines. The average female proportion in the temperature treated offspring increased by $11 \%$ up to $57.6 \%$ in the high line and decreased by $14 \%$ to $44.5 \%$ in the low line in the first generation of selection compared to $51.9 \%$ in the breeding base (Table 1). Only Wessels and HörstgenSchwark (2007) have also conducted a selection experiment for thermo-sensitivity of sex differentiation, but in tilapia. In their study, the selection criterion was the percentage of males in temperature treated progenies and a high line was built up similar to the one in the present investigation. The standardized realized response to selection in the up selected line was with 1.22 after two generations similar to the one with 1.2 in the present investigation after one generation of selection which might be due to the higher selection intensity in the present experiment.

The mean survival rates were significantly higher $(P<0.05,0.01)$ in the treatment groups than in the corresponding control groups, indicating that the sex ratios in the temperature-treated progenies could not be attributed to differential higher mortality of males or females in comparison to the control similar to the results of Craig et al. (1996). It cannot be excluded, however, that the tanks might have had an effect on survival rates, because the 30 day temperature treatment was not carried out in Zuger glasses, in which controls were kept during this time period. But more important is the fact that a higher mortality was not observed in the $18{ }^{\circ} \mathrm{C}$ treatment groups.

In the present experiment the realized selection responses in the first generation $\left(\Delta G_{R}\right)$ in relation to the applied selection $\left(S_{R}\right)$ were given by realized heritabilities $\left(h_{R}{ }^{2}\right)$ of 0.63 
for the high line and of 0.71 for the low line, resulting in an average realized heritability of $\mathrm{h}_{\mathrm{R}}{ }^{2}=0.67$ for both lines. Realized heritabilities obtained so far should be judged only as rough classifications of selection responses in relation to selection differentials, because one generation of selection can only indicate a tendency of the magnitude of obtainable selection responses. In similar experiments with tilapia, selection responses in relation to the applied selection over two generations were given by a slightly higher average realized heritability of $h_{R}^{2}=0.78$ (Wessels and Hörstgen-Schwark, 2007). The sex ratios in all full sib control groups of G0 and G1 were very close to a female proportion of $50 \%$. In addition, the realized selection differentials of the corresponding full sib control groups were $0.4 \%$ and $1.7 \%$ in the high and the low line respectively, thus no correlated response to selection could be observed regarding the proportion of females in full sib control groups in the course of the selection (Table 1).

Genetic sex determination is the acknowledged system of sex determination in rainbow trout with female homogamety $(\odot X X-\lesssim X Y)$ as in most other salmonids (Devlin and Nagahama, 2002). In species with an evident chromosome system like the rainbow trout, sex determination of an individual occurs during egg fertilization. This was demonstrated in previous studies for genetic sex control approaches by induced gynogenesis (Chourrout and Quillet, 1982; Chourrout, 1984; Quillet et al., 2002). From the theoretical point of view gynogenetic offspring is expected to be all female, nevertheless, unexpected 13 male fish out of 27 (48\%) fish were observed in offspring when mitotic gynogenesis was conducted by Quillet et al. (2002) in rainbow trout. In the present study, induced meiotic gynogenesis was conducted with a thermo-sensitive female spawner which showed male biased sex ratios in temperature treated batches of preliminary matings. The meiotic gynogenetic progeny consisted of $16 \%$ males in the temperature treated group and $4 \%$ males in the corresponding full sib control group. In tilapia, a number of studies by different authors support the conclusion that in Oreochromis niloticus, there are one or more minor sex-influencing loci that cause female to male sex reversal in XX individuals (Mair et al., 1991; Hussain et al., 1994; Müller-Belecke and Hörstgen-Schwark, 1995) and further the involvement of temperature in sex differentiation (Sarder et al., 1999; Tessema, 2001). Similar to these results in tilapia, Quillet et al. (2002) concluded that a comparable model in Oncorhynchus species exists and indications for this are also found in the present study.

To summarize, there might be two possible consumer- and environment-friendly ways to significantly increase the proportion of females in rainbow trout. The first would be di- 
rectly via selection of families which show a high percentage of females in their sex ratios after temperature treatment to build up a corresponding temperature sensitive line. In addition, the comparison of mean body weights at the age of 18 months between temperature treated fish and their corresponding full sib control groups were in favour of the temperature treated trout and revealed on average differences in weight of the same size as found between diploid and triploid rainbow trout of the same age (Poontawee et al., 2007). The higher water temperature during 30 days within the alevin stage seems to be responsible for these observed higher weights of temperature treated fish. Further generations of selection would show if high female proportions over $90 \%$ in temperature treated offspring could be achieved. However, due to the long generation interval of two to three years in rainbow trout it would become a long-term experiment. The second approach would be an indirect one via neo-males derived from temperature treated gynogenetic offspring, which could be used as mating partners to produce all female progenies. This could be a faster way than the selection for thermo-sensitivity to produce production populations with high female percentages. If suitable genetic markers for temperature sensitivity could be found (few observed outliers in the high and low line (G1) might indicate potential QTL) and a marker assisted selection would be possible, then "thermo-sensitivity" in both direction (male and female direction) could be integrated in existing breeding programmes and both alternatives, selection and gynogenesis could be combined, when appropriate.

\section{Acknowledgement}

The authors want to express their gratitude to Mr. Daniel Kaffke and Mr. Heiko Hartmann for their excellent technical assistance. This work was supported by the BLE (Nr. 514-33.22/03HS037). 
Table 1. Survival rate, number of fish sexed and sex ratios of treatment $\left(18{ }^{\circ} \mathrm{C}\right.$ for 30 days $)$ and control groups $\left(12{ }^{\circ} \mathrm{C}\right)$ in the base population (G0) and in the high and low line in the first generation of selection (G1)

\begin{tabular}{|c|c|c|c|c|c|c|c|c|}
\hline \multirow[b]{2}{*}{ Generation $^{1}$} & \multicolumn{3}{|c|}{ Treatment } & \multicolumn{5}{|c|}{ Control $\left(12^{\circ} \mathrm{C}\right)$} \\
\hline & Line $^{2}$ & $\begin{array}{c}\text { Survival }^{3} \\
\%\end{array}$ & $\begin{array}{c}\text { Sexed } \\
n\end{array}$ & $\begin{array}{c}\text { Female } \\
\%\end{array}$ & $\begin{array}{c}\text { Survival }^{3} \\
\%\end{array}$ & $\begin{array}{c}\text { Sexed } \\
n\end{array}$ & $\begin{array}{c}\text { Female } \\
\%\end{array}$ & $\chi^{2}$ \\
\hline G0 $(n=95)$ & - & $91.3^{c}$ & 10.499 & $51.9 \pm 8.9$ & 82.0 & 10.265 & $49.3 \pm 3.1$ & 1.99 \\
\hline $\mathrm{G} 1(n=18)$ & High & $92.2^{\mathrm{c}}$ & 1.941 & $57.6^{\mathrm{c}} \pm 4.7$ & 86.2 & 1842 & $49.5 \pm 1.8$ & 1.22 \\
\hline$(n=14)$ & Low & $90.4^{\mathrm{a}}$ & 1.455 & $44.5^{\mathrm{c}} \pm 4.3$ & 87.0 & 1465 & $49.6 \pm 2.1$ & 0.83 \\
\hline
\end{tabular}

${ }^{1}$ G0: base population, G1: first generation of selection;

${ }^{2}$ line with high/low sensitivity to temperature treatment during sex differentiation (starting $42 \mathrm{dpf}$ );

${ }^{3}$ Survival rate of progeny at the end of the temperature treatment, 72 days post fertilization;

$\mathrm{a}, \mathrm{b}, \mathrm{c}$ significantly different from full sib controls $(P<0.05,0.01,0.001)$;

$\chi^{2}=$ values for deviation of the full sib control's sex ratios from 1:1. 
Table 2. Total number of families ( $n$ Total), number of families selected ( $n$ selected), proportion of families selected ( $p$ selected), realized selection differential $\left(S_{\mathrm{R}}\right.$ in $\%$ females), standardized realized selection differential $\left(S_{R}\right.$ in $\left.\mathrm{SD}\right)$, realized response to selection $\left(\Delta \mathrm{G}_{\mathrm{R}}\right)$ and standardized realized response to selection $\left(\Delta \mathrm{G}_{\mathrm{R}}\right.$ in SD) in treatment groups in the high and low line in the base population (G0) and the first generation of selection (G1)

\begin{tabular}{|c|c|c|c|c|c|c|c|c|}
\hline Generation & Line $^{1}$ & $\begin{array}{c}\text { Total } \\
n\end{array}$ & $\begin{array}{c}\text { Selected } \\
n\end{array}$ & $\begin{array}{c}\text { Selected } \\
p\end{array}$ & $\begin{array}{c}\mathrm{S}_{\mathrm{R}} \\
(\% \text { females })\end{array}$ & $\begin{array}{c}S_{R} \\
\text { in } S D\end{array}$ & $\begin{array}{c}\Delta \mathrm{G}_{\mathrm{R}} \\
(\% \text { females })\end{array}$ & $\begin{array}{l}\Delta \mathrm{G}_{\mathrm{R}} \\
\text { in } \mathrm{SD}\end{array}$ \\
\hline \multirow[t]{2}{*}{ G0 } & High & 95 & 6 & 0.063 & 9.0 & 2.6 & - & - \\
\hline & Low & 95 & 6 & 0.063 & -10.4 & -2.2 & - & - \\
\hline \multirow[t]{2}{*}{ G1 } & High & 18 & - & - & - & - & 5.7 & 1.2 \\
\hline & Low & 14 & - & - & - & - & -7.4 & -1.7 \\
\hline
\end{tabular}


Chapter 4

General Discussion 
The results from chapter 2 and 3 are shortly summarized in this chapter in order to get a comprehensive overview about the research results of the present study and the integration into the literature context about sex determination and differentiation of the rainbow trout species. Furthermore, the possible practical benefits of the gained scientific results to large rainbow trout farmers are revealed as well as their possible integration into worldwide aquaculture of large rainbow trout $(>1.2 \mathrm{~kg})$ production.

In experiments of van den Hurk and Lambert (1982) and Baroiller et al. (1999) effect of temperature treatments on sex ratios could not be found, however, in relation to the present study they used different temperature regimes and had only relatively small sample sizes and a limited breeding base. In the present experiment progenies from single pair matings of spawners randomly selected from six different rainbow trout broodstocks kept at the Experimental Trout Farm Relliehausen were studied for thermo-sensitivity of their sex ratios.

Preliminary studies with $16{ }^{\circ} \mathrm{C}$ and $20{ }^{\circ} \mathrm{C}$ for 30 days clearly showed, that $16{ }^{\circ} \mathrm{C}$ had only little effect to sex ratios, when progenies were exposed to this temperature level, as well as $20{ }^{\circ} \mathrm{C}$ for 30 days starting 42 days post hatching was too intensive and resulted in significantly lower survival rates than the corresponding rates from the full sib control groups. For this reason, the applied temperature treatment of $18{ }^{\circ} \mathrm{C}$ for 30 days was used continuously during the whole experiment, because it was the highest one which did not cause significantly lower survival rates in the treatment groups than in the corresponding full sib controls which were kept at $12{ }^{\circ} \mathrm{C}$. The results of this experiment clearly showed that there must be differences between populations and families within populations regarding thermo-sensitivity in the range of no (population V) to significantly higher (populations I, II, IV and VI) or significantly lower (population III) percentages of females in the offspring.

Similar results were also gained in another Oncorhynchus species, the sockeye salmon (O. nerka). Here, Azuma et al. (2004) showed the possibility of sex reversal from genetic females to functional males by a temperature treatment regime of $18{ }^{\circ} \mathrm{C}$ starting from 42 to 151 days post fertilization in comparison to $9{ }^{\circ} \mathrm{C}$ for the corresponding control groups. A similar phenomenon was observed in the underlying study when progenies from the population III were treated with the temperature regime used by Azuma et al. (2004). Besides, Komrakowa (2006) found a sex marker called variant A of OmyP9 RsaI (Iturra et al., 2001), which was present in the same population III and almost exclu- 
sively found in males. However, this variant A was also found in three additional populations, populations I, II and VI.

It must be restrictively mentioned that, relative to the present study, Azuma et al. (2004) worked with an all-female population, so that the authors could not study a sex reversal from genetic males to functional females by elevated temperatures. Whereas Craig et al. (1996) found strongly female-biased sex ratios (62\% to $84 \%$ female) in different populations and population crosses of sockeye salmon when he exposed fertilized eggs to higher temperatures $\left(10.4{ }^{\circ} \mathrm{C}-12.0^{\circ} \mathrm{C}\right.$; control: $\left.8.3^{\circ} \mathrm{C}-9.7{ }^{\circ} \mathrm{C}\right)$ during embryonic development (starting at $360 \mathrm{dpf}$ ).

To shortly summarize, depending on the genetic background of the sockeye salmon population, temperature manipulation during incubation and hatching phases could alter the sex ratio (Craig et al., 1996). Similar results were gained in the present study which clearly showed female biased sex ratios in progenies of different brood stocks when they were exposed to higher temperatures post hatching. In the underlying experiment temperature treatment was conducted only post hatching when two third of the yolk sac of the fry was absorbed and similar survival rates were given for treatment and control groups. Temperature treatments during the hatching phase or even during the incubation phase in rainbow trout cause high mortality, therefore a clear proof of temperature sensitivity on the sex ratio of progeny could not be expected.

In general, these results imply that temperature is able to increase or decrease the proportion of females. However, temperature regimes between the both studies as well as the range of distortion in female percentages were considerably different (20\% in this study versus $28 \%$ of females compared to controls in Craig et al., 1996).

In both studies (Craig et al. (1996) and the present study) the sex ratios in temperaturetreated progenies could not be attributed to differential higher mortality of females or males, because treatment groups had higher or at least similar survival rates after temperature treatment than the corresponding control groups. In the underlying study, survival rates in temperature treated groups $\left(18^{\circ} \mathrm{C}\right)$ were often significantly higher than in the corresponding full sib control groups $\left(12^{\circ} \mathrm{C}\right)$. Nevertheless, it cannot be excluded, that the tanks might have had an effect on survival rates, because the 30 day temperature treatment was not carried out in Zuger glasses, in which the controls were kept during this time period due to limited space in the hatchery. However, both groups, treatment groups and controls, had the same water quality of the same water source with compara- 
ble water quality parameters except temperature. All in all, the key point is that higher mortality of one sex did not play a decisive role in the $18{ }^{\circ} \mathrm{C}$ treatment groups.

Until today, high repeatability of the response of sex ratios to temperature treatments was only proven in tilapia (O. niloticus) by Tessema et al. (2006). The authors showed that replicated $36{ }^{\circ} \mathrm{C}$ - treated spawns varied only by a range of $1.7 \%$ to $6.2 \%$. Also in the present study similar repeatable results were observed with a comparable narrow range of female distorted sex ratios from $0.4 \%$ to $5.8 \%$ (Table 2). Furthermore, successive matings with proven repeatability (for example $\delta 5 \times q 15$ and $\delta 6 \times q 16$ ) which differed significantly $(P<0.05)$ from the corresponding control groups could be a reliable indication for a genetic background of the sensitivity of temperature treatment on sex differentiating mechanisms as it was already proven for tilapia by Wessels and Hörstgen-Schwark (2007).

Consistent with the findings of Tessema et al. (2006) in tilapia, the underlying results give evidence for the contribution of both parents in rainbow trout, males and females, to the different sex ratios after temperature treatment (shown in Table 3). Depending on the maternal mating partner, paternal half sibs showed significantly different sex ratios

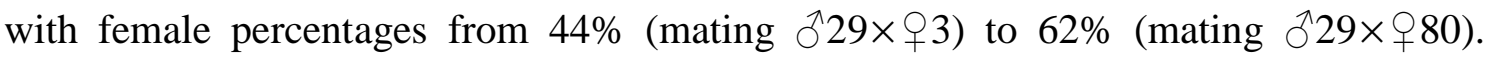
Nevertheless, significantly different sex ratios with female percentages from $48.8 \%$ (mating $+14 \times \Uparrow 64)$ to $66.9 \%$ (mating $q 14 \times \Uparrow 42, P<0.01$ ) were also noticed for maternal half sibs (mating $q 14 \times \widehat{\jmath} 64$ and $\widehat{\delta} 42$ ). These findings also showed a clear paternal and maternal influence on sex ratios after temperature treatment $\left(18^{\circ} \mathrm{C}\right)$.

To summarize, the results obtained suggest that rainbow trout is a thermo-sensitive species and temperature can influence gonadal sex differentiation of the individuals during the early development stages.

The main aim of the second part of the present experiment was to evaluate the possibility of altering the sex ratio in progenies of rainbow trout (O. mykiss) families through selection of thermo-sensitive families with unbalanced sex ratios in their temperature treated offspring.

It was possible to select for increased (high line) as well as for decreased female proportions (low line) in the selection lines. The average female proportion in the temperature treated offspring increased by $11 \%$ up to $57.6 \%$ in the high line and decreased by $14 \%$ to $44.5 \%$ in the low line in the first generation of selection compared to $51.9 \%$ in the breeding base (Table 1). Until now, a selection experiment for thermo-sensitivity of sex 
differentiation has only been conducted by Wessels and Hörstgen-Schwark (2007) for tilapia. In the author's study, the selection criterion was the percentage of males in temperature treated progenies, building up a high line similar to the one in the underlying investigation. Also the standardized realized response to selection in the up selected line was with 1.22 after two generations similar to the one with 1.2 in the present investigation after one generation of selection. The reason for this could be the chosen higher selection intensity in the present experiment.

In the underlying study the realized heritability $\left(\mathrm{h}_{\mathrm{R}}^{2}\right)$ in the high line was 0.63 and in the low line 0.71 , this resulted in an average realized heritability of $\mathrm{h}_{\mathrm{R}}^{2}=0.67$ for both lines. In tilapia, a slightly higher average realized heritability of $h^{2}{ }_{R}=0.78$, but over two generations of selection, were estimated by Wessels and Hörstgen-Schwark (2007). The sex ratios in all full sib control groups of G0 and G1 were very close to a female proportion of 50\%, what is also similar to the findings of Wessels and Hörstgen-Schwark (2007).

The induced meiotic gynogenesis in the underlying experiment was conducted with a thermo-sensitive female spawner, which showed male distorted sex ratios in temperature treated batches of preliminary matings. Here, $16 \%$ males within the meiotic gynogenetic progeny ( 85 females and 16 males) in the temperature treated group and 4\% males (104 females and 4 males) in the corresponding full sib control group were observed.

As it is widely known, genetic sex determination is the acknowledged system of sex de-

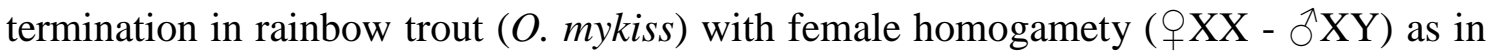
most other salmonids (Devlin and Nagahama, 2002). In species like rainbow trout with a basic chromosome system, sex determination of an individual takes place during the process of egg fertilization. This was shown in previous investigations for genetic sex control approaches by induced gynogenesis (Chourrout (1984), Chourrout and Quillet (1982), Quillet et al. (2002)). Nevertheless, 13 male fish out of 27 (48\%) fish occurred unexpectedly in the offspring, when mitotic gynogenesis was conducted (Quillet et al., 2002) in rainbow trout. Similar happened for tilapia (O. niloticus), Hussain et al. (1994) found 19 males in 39 (47.5\%) mitotic gynogenetic offspring and Müller-Belecke and Hörstgen-Schwark (1995) had also 42 males $(26.1 \%)$ in 161 mitotic gynogenetic progeny. Unexpected maleness in tilapia was also found in meiotic gynogenetic offspring, when Mair et al. (1991) observed 8 males in 187 meiotic gynogenetic fish (4.3\% males) and Hussain et al. (1994) noticed 3 males in 40 (7.5\%) meiotic gynogenetic tilapia. 
Similar to these results in tilapia, Quillet et al. (2002) concluded a comparable model in Oncorhynchus species exists and indications for this are also found in the present study.

Finally, there might be two possible consumer- and environment-friendly ways to significantly increase the proportion of females in rainbow trout.

The first would be directly via selection of families which show a high percentage of females in their sex ratios after temperature treatment to build up a corresponding temperature sensitive line. In addition, the comparison of mean body weights at the age of 18 months between temperature treated fish and their corresponding full sib control groups were in favour of the temperature treated trout and revealed on average differences in weight of the same size as found between diploid and triploid rainbow trout of the same age (Poontawee et al., 2007). The higher water temperature during 30 days within the alevin stage seems to be responsible for these observed higher weights of temperature treated fish. Further generations of selection would show if high female proportions over $90 \%$ in temperature treated offspring could be achieved. However, due to the long generation interval of two to three years in rainbow trout it would become a long-term experiment.

The second approach would be an indirect one via neo-males derived from temperature treated gynogenetic offspring, which could be used as mating partners to produce all female progenies. This could be a faster way than the selection for thermo-sensitivity to produce production populations with high female percentages. If suitable genetic markers for temperature sensitivity could be found (few observed outliers in the high and low line (G1) might indicate potential QTL) and a marker assisted selection would be possible, then "thermo-sensitivity" in both direction (male and female direction) could be integrated in existing breeding programmes and both alternatives, selection and gynogenesis could be combined, when appropriate.

Owing to the success this production method (direct or indirect method) in Europe it should not be unrealistic that the production of large rainbow trout $(>1.2 \mathrm{~kg}$ ) could increase significantly into several European countries. 


\section{References}

Abucay, J.S., Mair, G.C., Skibinsky, D.O.F. and Beardmore, J.A., 1999. Environmental sex determination: the effect of temperature and salinity on sex ratio in Oreochromis niloticus L., Aquaculture 173, 219 - 234.

Azuma, T., Takeda, K., Doi, T., Muto, K., Akutsu, M., Sawada, M., Adachi, S., 2004. The influence of temperature on sex determination in sockeye salmon Oncorhynchus nerka. Aquaculture 234, $461-473$.

Baroiller, J.F., Fostier, A., Cauty, C., Rognon, X., Jalabert, B., 1993. Effects of high rearing temperatures on sex ratio of progeny from sex-reversed males of Oreochromis niloticus. In: Pullin, R.S.V., Lazard, J., Legendre, M., Amon Kothias, J.B. and Pualy, D. (Eds.). The Third International Symposium on Tilapia in Aquaculture. ICLARM Conf. Proc. 41.

Baroiller, J.F., Chourrout, D., Fostier, A. and Jalabert, B., 1995a. Temperature and sex chromosomes govern sex ratios of the mouthbrooding cichlid fish Oreochromis niloticus. J. Exp. Zool. 273, 216 - 223.

Baroiller, J.F., Clota, F., Geraz, E., 1995b. Temperature sex determination in two tilapia. Oreochromis niloticus and the red tilapia (Red Florida Strain): Effect of high and low temperature. In: Goetz, F.W., Thomas, P. (Eds.), Proceedings of the $5^{\text {th }}$ international Symposium on the Reproductive Physiology of Fish, 2-8 July 1995. The University of Texas (Austin), USA, pp.158- 160.

Baroiller, J.F., Guiguen, Y. and Fostier, A., 1999. Endocrine and environmental aspects of sex differentiation in fish. Cell. Mol. Life Sci. 55, 910 - 931.

Baroiller, J.-F., D’Cotta, H., Bezault, E., Wessels, S., Hörstgen-Schwark, G., 2009. Tilapia sex determination: Where temperature and genetics meet. Comparative Biochemistry and Physiology A, 153, 30-38. 
Billard, R., 1992. Reproduction in rainbow trout: sex differentiation, dynamics of gametogenesis, biology and preservation of gametes. Aquaculture 100, 263 - 298.

Bohl, M., 1999. Zucht und Produktion von Süßwasserfischen. 2., neu überarbeitete Auflage, DLG-Verlag, Frankfurt am Main, pp. 216-331.

Bull , J.J., 1980. Sex determination in reptiles. Quar. Rev. Biol. 50, 3 - 21.

Bull, J.J. and Vogt, R.C., 1979. Temperature dependent sex determination in turtles. Science 206, $1186-1188$.

Bulmer, M., 1987. Sex determination in fish. Nature 326, 440 - 441.

Charnier, M., 1966. Action de la temperature sur la sex ratio chez lemryon d'Agama agama (Agamidae, Lacertilien). Soc. Biol. Quest. Af., 160, 620 - 622 (cited in Pieau et al., 1994).

Charnov, E.L. and Bull, J.J., 1977. When is sex environmentally determined? Nature $266,828-830$.

Chourrout, D., 1984. Pressure induced retention of second polar body and suppression of first cleavage in rainbow trout: production of all-triploids, all-tetraploids and heterozygous and homozygous diploid gynogenetics. Aquaculture 36, 111-126.

Chourrout, D., Quillet, E., 1982. Induced gynogenesis in the rainbow trout: sex and survival of progenies. Production of all triploid populations. Theor. Appl. Genet. 63, $201-205$.

Conover, D.O. and Kynard, B.E., 1981. Environmental sex determination: Interaction of temperature and genotype in a fish. Science $213,577-579$.

Conover, D.O. and Heins, S.W., 1987a. Adaptive variation in environmental and genetic sex determination in a fish. Nature 326, $496-498$. 
Conover, D.O. and Heins, S.W., 1987b. The environmental and genetic components of sex ratio in Menidia menidia (Pisces: Atherenidae). Copeia, 732 - 743.

Conover, D.O., and van Voorhees, D.A., 1990. Evolution of a balanced sex ratio by frequency dependent selection in a fish. Science 250, $1556-1558$.

Conover, D.O. van Voorhees, D.A. and Ethisham, A., 1992. Sex ratio selection and the evolution of environmental sex determination in laboratory populations of Menidia menidia. Evolution 46, 1722 - 1730.

Craig, J.K., Foote, C.J., Wood, C.C., 1996. Evidence for temperature-dependent sex determination in sockeye salmon (Oncorhynchus nerka). Can. J. Fish. Aquat. Sci. $53,141-147$.

Devlin, R.C., Nagahama, Y., 2002. Sex determination and sex differentiation in fish: an overview of genetic, physiological and environmental influences. Aquaculture $208,191-364$.

Docker, M.F. and Beamish, F.W.B., 1994. Age, growth and sex ratio among populations of least brook lamprey, Lampetra aepypetra, larvae: An argument for sex determination. Environmental Biology of Fishes, 41 (1-4), 191 - 205.

Falconer, D.S., Mackay, T.F.C., 1996. Introduction to quantitative Genetics. Longman, Essex, England, 464 pp.

FAO, 2008a. Food and Agricultural Organisation of the United Nations. Cultured Aquatic Species Information Programme. Oncorhynchus mykiss (Walbaum, 1792).

FAO, 2008b. Food and Agricultural Organisation of the United Nations. Aquaculture Production Statistics. Global Production of rainbow trout 1950 - 2006.

FEAP, 2007. Federation of European Aquaculture Producers. Large rainbow trout production in Europe. 
Ferguson, M.W.J. and Joanen, T., 1982. Temperature of egg incubation determines sex in Alligator mississipiensis. Nature 296, 850 - 853.

Fisher, R.A., 1930. The genetic theory of natural selection. Cleredon, Oxford (cited in Trivers and Willard, 1973).

Grant, V.J., 1996. Sex determination and maternal dominance hypothesis. Human Reproduction (Oxford), 11 (11), $2371-2375$.

Guerrero, R.D., Shelton, W.L., 1974. An aceto-camine squash method for sexing juvenile fish. Prog. Fish Cult. 36, 56.

Gutzke, W.H.N. and Crews, D., 1988. Embryonic temperature determines adult sexuality in a reptile. Nature $332,832-834$.

Heiligenberg, W., 1965. Color polymorphism in the males of an African cichlid fish. J. Zool. 146, 95 - 97.

Hörstgen-Schwark, G., 1993. Selection experiments for improving "pan-size" body weight of rainbow trout (Oncorhynchus mykiss). Aquaculture 112, $13-24$.

Hörsten-Schwark, G., Fricke, H, Langholz, H.-J., 1986. The effect of strain crossing on the production performance in rainbow trout. Aquaculture, 57, $141-152$.

Hunter, G.A. and Donaldson, E.M., 1983. Hormonal sex control and its application to fish culture. In: Hoar, W.S., Randall, D.J. and Donaldson, E.M. (Ed.), Fish Physiology, IXB. Academic Press, New York, pp. 203 - 303.

Hussain, M.G., McAndrew, B.J., Penman, D.J., Sodusk, P., 1994. Estimate gene centromere recombination frequencies in gynogenetic diploids of Oreochromis niloticus (L.), using alloenzymes, skin color and a putative sex de-termination locus (SDL-2). In: Beaumont, A.R. (Ed.), Genetics and Evolution of Aquatic Organisms. Chapman and all, 2 - 6 Boundary Row, London SEI 8HN, UK, pp. 502 - 509. 
Iturra, P., Bagley, M., Vergara, N., Imbert, P., Medrano, J.F., 2001. Development and characterization of DNA sequences Omy P9 associated with the sex chromosomes in rainbow trout. J. Heredity 86. $412-419$.

Jalabert, B., Billard, R. and Chevassus, B., 1975. Preliminary experiments on the sex control in trout: production of sterile fishes and simultaneous self-fertilizable hermaphrodites. Ann. Biol. Anim. Biochim. Biophys. 15, 19 - 28.

Komen, J., Boer de, P. and Richter, C.J.J., 1992a. Male sex reversal in gynogenetic XX females of common carp (Cyprinus carpio L.) by a recessive mutation in a sexdetermining gene. J. Heredity 83, $431-434$.

Komen, J., Wiegerts, G.F., Ginneken van, V.J.T., Eding, E.H. and Richter, C.J.J., 1992b. Gynogenesis in common carp (Cyprinus carpio L.). III. The effect of inbreeding on gonadal development of heterozygous and homozygous offspring. Aquaculture $104,51-66$.

Komen, J., Spaans, P., Zhang, D.M. and Richter, C.J.J., 1995. Sex determination in common carp (Cyprinus carpio L.). Aquaculture 137, 106.

Komrakova, M., 2006. Preservation of eggs and genetic sex discrimination in rainbow trout (Oncorhynchus mykiss). Dissertation, University of Göttingen, 177 pp., CUVILLIER VERLAG Göttingen, ISBN-13: 9783867270663.

Krueger, W. H. and Oliveira, K., 1999. Evidence for environmental sex determination in the American eel (Anguilla rostrata). Environmental Biology of Fishes, 55 (4), $381-389$.

Lebrun, C., Billard, R. and Jalabert, B., 1982. Changes in the number of germ cells in the gonads of the rainbow trout Salmo gairdneri during the first 10 post-hatching weeks. Reprod. Natr. Dev. 22. 405 - 412. 
Magerhans, A., Müller-Belecke, A., Hörstgen-Schwark, G., 2009. Effect of rearing temperature post hatching on sex ratios of rainbow trout (Oncorhynchus mykiss) populations. Aquaculture 294, $25-29$.

Mair, G.C., Scott, A.G., Penman, D.J., Beardmore, J.A., Skibinski, D.O.F., 1991. Sex determination in the genus Oreochromis niloticus. 1. sex reversal, gynogenesis and triploidy in O. niloticus (L.). Theor. Appl. Genet. 82, 144-152.

McCormick, S.D. and Naiman, R.J., 1984. Some determinants of maturation in brook trout, Salvelinus fontinalis. Aquaculture 43, $269-278$.

McKay, L.R., Ihssen, P.E., Friars, G.W., 1986. Genetic parameters of growth in rainbow trout, Salmo gairdneri, as a function of age and maturity. Aquaculture 58, 241 254.

Morkramer, S., Hörstgen-Schwark, G., Langholz, H.J., 1985. Comparison of different European rainbow trout populations under intensive production conditions. Aquaculture $44,303-320$.

Müller-Belecke, A. and Hörstgen-Schwark, G., 1995. Sex determination in tilapia (Oreochromis niloticus) sex ratios in homozygous gynogenetic progeny and their offspring. Aquaculture 137, $57-65$.

Nagler, J.J., Bouma, J., Thorgaard, G.H., Dauble, D.D., 2001. High incidence of male specific genetic marker in phenotypic female chinook salmon from the Columbia River. Environ Health Perspect 109, 67-69.

Padoa, E., 1939. Observations ulterieures sur la differentiation du sexe, normale et modifiée par l'administration d'homme folliculaire, chez la truite irridée Salmo irideus. Biomorphosis, 1. 337 - 354 (cited in Billard, 1992).

Pieau, C., 1972. Effects de la temperature sur le development des glandes genitales chez les embryons de deux Chelonians, Embis orbicularis L. and Tesudo graeca L.C.R. Acad. Sci. Paris 274, 719 - 722 (cited in Pieau et al., 1994). 
Pieau, C., 1996. Temperature variation and sex determination in reptiles. Bioessays 18, $19-26$.

Pieau, C., Girondot, M., Ricard, M., Desvage, G., Dorrizi, M. and Zaborski, P., 1984. Temperature sensitivity of sexual differentiation in the European turtle: Hormonal involvement. J. Exp. Zool. 270, 86 - 94.

Pillay, T.V.R., 1990. Aquaculture. University Press, Cambridge, 156 - 173.

Poontawee, K., Werner, C., Müller-Belecke, A., Hörstgen-Schwark, G., Wicke, M., 2007: Flesh qualities and muscle fiber characteristics in triploid and diploid rainbow trout. J. Appl. Ichthyol. 23, 273-275.

Purdom, C.E., 1995. Genetics and fish breeding. Chapman \& Hall, London, 79-81, $192-203$.

Quillet, E., Aubard, G., Queau, I., 2002. Mutation in a sex-determining gene in rainbow trout: detection and genetic analysis. J. Heredity 93, $91-99$.

Römer, U. and Beisenherz, W., 1996. Environmental determination of sex in Apistogramma (Cichilidae) and two other fresh water fishes (Teleostei). J. Fish. Biol. 48, $714-725$.

Rubin, D.A., 1985. Effect of $\mathrm{pH}$ on the sex ratio in cichlids and poeciliid (Teleostei). Copeia, $133-135$.

Sarder, M.R.I., Penman, D.J., Myers, J.M., McAndrew, B.J., 1999. Production and propagation of fully inbred clonal lines in the Nile tilapia (Oreochromis niloticus L.). J. Exp. Zool. 284, 675-685.

Smith, G.R. and Stearley, R.F., 1989. The classification and scientific names of rainbow trout and cutthroat trout. Fisheries, 14 (1), $4-10$. 
St.-Clair, R.C., 1998. Patterns of growth and sexual size dimorphism in two species of box turtles with environmental sex determination. Oecologia-Berlin, 115(4), 501507.

Strüssmann, C.A., Moriyama, S., Hanke, E.F., Cota, J.C.C. and Takashima, F., 1996. Evidence of thermo-labile sex determination in pejerrey. J. Fish Biol. 48, $714-725$.

Steffens, W., 1981. Moderne Fischwirtschaft - Grundlagen und Praxis. Verlag J. Neumann - Neumann, Melsungen, 128 - 129.

Sullivan, J.A. and Schultz, R.J., 1986. Genetic and environmental basis of variable sex ratios in laboratory strains of Poeciliopsis lucida. Evolution 40, $152-158$.

Takashima, F., Patino, R. and Nomura, M., 1980. Histological studies on the sex differentiation in rainbow trout. Bull. Jpn. Sci. Fish. 46, 1317 - 1322 (cited by Billard, 1992).

Tessema, M., 2001. Sex ratios in Tilapia (Oreochromis niloticus): Interaction between genotype and temperature. Dissertation, University of Göttingen, Germany, Cuvillier Verlag ISBN 3-89873-143-X, 156 Seiten.

Tessema, M., Müller-Belecke, A., Hörstgen-Schwark, G., 2006. Effect of rearing temperatures on the sex ratios of Oreochromis niloticus populations. Aquaculture 258, $270-277$.

Trivers, R.L. and Willard, D.E., 1973. Natural selection of parental ability to vary the sex ratio of offspring. Science 179, $90-91$.

Upadhyay, S.N., 1977. Morphologie des gonades immatures et étude expérimentale de l'induction de la gamétogénèse chez la truite arc-en-ciel juvénile Salmo gairdneri R. Thèse Doct. Es. Sci. Nat. Univ. Paris VI, 111p. (cited by Billard, 1992). 
Van den Hurk, R. and Slof, G.A., 1981. A morphological and experimental study of gonadal sex differentiation in rainbow trout, Salmo gairdneri. Cell. Tissue Res. 218, $487-497$.

Van den Hurk, R., Lambert, J.G.D., 1982. Temperature and steroid effects on gonadal sex differentiation in rainbow trout. In: Richter, C.J.J., Goos, H.J.T. (Eds.), Proceeding of the International Symposium on the Reproductive Physiology of Fish. 2-6 August, 1982, Pudoc., Wageningen, pp. 69 - 72.

Viets, B.E., Tousignant, A., Ewert, M.A., Nelson, C.E. and Crews, D., 1993. Temperature dependent sex determination in the Leopard gecko, Eublepharis macularius. J. Exp. Zool. 265, $679-683$.

Viets, B.E., Ewert, M.A., Talent, L.G., Nelson, C.E., 1994. Sex determining mechanisms in squamate reptiles. J. Exp. Zool. 270, 45 - 56.

Wessels, S., Hörstgen-Schwark, G., 2007. Selection experiments to increase the proportion of males in Nile tilapia (Oreochromis niloticus) by means of temperature treatment. Aquaculture, 272, $80-87$.

Wotton, R.J., 1982. Environmental factors in fish reproduction. In: Richter, C.J.J., Goos, H.J.Th. (Eds.), Proc. Intern. Symp. Reprod. Physiol. Fish, Wageningen, The Netherlands, PUDOC, Wageningen, 210 - 219.

Wood, F.E. and Wood, J.R., 1982. Sex ratios in captive-reared green turtles, Chelonie mydas. Copeia, $482-485$.

Yntema, C.L., 1979. Temperature levels and periods of sex determination during incubation of eggs of Chelydra serpentine. J. Morph. 159, 17 - 28. 


\section{Appendix}

Raw data of temperature effects in different populations, shown in table 1 of the publication no. 1

\begin{tabular}{|c|c|c|c|c|c|c|c|c|}
\hline Population & $\begin{array}{c}\text { Mating } \\
\text { No. }\end{array}$ & Treatment $^{1}$ & $\begin{array}{c}N \text { in Treat- } \\
\text { ment }\end{array}$ & $\begin{array}{c}N \text { after } \\
\text { Treatment }\end{array}$ & $\begin{array}{c}\text { Survival }^{2} \\
\text { Rate, \% }\end{array}$ & $N$ sexed & $\begin{array}{l}\text { Sex ratio } \\
\text { in } \%\end{array}$ & Sig. ${ }^{3}$ \\
\hline I & 1 & 1 & 200 & 185 & 92,5 & 84 & 51,2 & \\
\hline I & 1 & 2 & 185 & 182 & 98,4 & 48 & 56,3 & \\
\hline I & 2 & 1 & 200 & 185 & 92,5 & 84 & 51,2 & \\
\hline I & 2 & 2 & 390 & 342 & 87,7 & 89 & 58,4 & \\
\hline I & 3 & 1 & 500 & 472 & 93,6 & 89 & 50,6 & \\
\hline I & 3 & 2 & 400 & 353 & 88,3 & 86 & 59,3 & \\
\hline I & 4 & 1 & 400 & 363 & 90,8 & 83 & 51,8 & \\
\hline I & 4 & 2 & 430 & 412 & 95,8 & 104 & 64,6 & \\
\hline II & 1 & 1 & 200 & 180 & 90,0 & 119 & 49,2 & \\
\hline II & 1 & 2 & 200 & 168 & 84,0 & 133 & 58,9 & \\
\hline II & 2 & 1 & 200 & 181 & 90,5 & 79 & 51,3 & \\
\hline II & 2 & 2 & 200 & 181 & 90,5 & 67 & 63,6 & \\
\hline II & 3 & 1 & 200 & 179 & 89,5 & 99 & 48,5 & \\
\hline II & 3 & 2 & 200 & 186 & 93,0 & 83 & 64,6 & $*$ \\
\hline II & 4 & 1 & 200 & 168 & 84,0 & 67 & 52,2 & \\
\hline II & 4 & 2 & 200 & 182 & 91,0 & 70 & 58,8 & \\
\hline II & 5 & 1 & 500 & 361 & 72,2 & 89 & 51,7 & \\
\hline II & 5 & 2 & 500 & 288 & 57,6 & 88 & 54,5 & \\
\hline II & 6 & 1 & 500 & 412 & 82,4 & 91 & 48,4 & \\
\hline II & 6 & 2 & 500 & 445 & 89,0 & 73 & 54,8 & \\
\hline II & 7 & 1 & 500 & 371 & 74,2 & 85 & 48,0 & \\
\hline II & 7 & 2 & 400 & 325 & 81,3 & 85 & 69,4 & $* *$ \\
\hline III & 1 & 1 & 150 & 116 & 77,0 & 95 & 47,7 & \\
\hline III & 1 & 2 & 150 & 125 & 83,0 & 98 & 37,8 & \\
\hline III & 2 & 1 & 300 & 160 & 53,3 & 105 & 48,6 & \\
\hline
\end{tabular}




\begin{tabular}{|c|c|c|c|c|c|c|c|c|}
\hline III & 2 & 2 & 300 & 205 & 68,3 & 114 & 36,8 & \\
\hline III & 3 & 1 & 120 & 80 & 66,7 & 78 & 55,1 & \\
\hline III & 3 & 2 & 150 & 110 & 73,3 & 87 & 34,5 & $* *$ \\
\hline III & 4 & 1 & 300 & 254 & 84,7 & 93 & 50,5 & \\
\hline III & 4 & 2 & 300 & 265 & 88,3 & 95 & 32,1 & $* *$ \\
\hline III & 5 & 1 & 300 & 261 & 87,0 & 93 & 52,7 & \\
\hline III & 5 & 2 & 300 & 282 & 94,0 & 91 & 38,4 & $*$ \\
\hline IV & 1 & 1 & 200 & 172 & 86,0 & 79 & 46,7 & \\
\hline IV & 1 & 2 & 200 & 179 & 89,5 & 90 & 56,7 & \\
\hline IV & 2 & 1 & 200 & 170 & 85,0 & 85 & 48,8 & \\
\hline IV & 2 & 2 & 200 & 183 & 91,5 & 112 & 65,8 & $*$ \\
\hline IV & 3 & 1 & 200 & 178 & 89,0 & 80 & 47,4 & \\
\hline IV & 3 & 2 & 200 & 188 & 94,0 & 119 & 55,6 & \\
\hline IV & 4 & 1 & 200 & 177 & 88,5 & 83 & 47,6 & \\
\hline IV & 4 & 2 & 200 & 181 & 90,5 & 117 & 53,8 & \\
\hline IV & 5 & 1 & 200 & 167 & 83,5 & 84 & 51,2 & \\
\hline IV & 5 & 2 & 200 & 179 & 89,5 & 165 & 59,5 & \\
\hline IV & 6 & 1 & 200 & 165 & 82,5 & 89 & 53,8 & \\
\hline IV & 6 & 2 & 200 & 173 & 86,5 & 146 & 54,1 & \\
\hline V & 1 & 1 & 300 & 265 & 88,3 & 87 & 48,3 & \\
\hline V & 1 & 2 & 300 & 295 & 98,3 & 130 & 53,1 & \\
\hline V & 2 & 1 & 300 & 218 & 72,7 & 102 & 46,7 & \\
\hline V & 2 & 2 & 300 & 282 & 94,0 & 91 & 53,8 & \\
\hline V & 3 & 1 & 300 & 202 & 67,3 & 84 & 52,4 & \\
\hline V & 3 & 2 & 300 & 236 & 78,7 & 91 & 47,3 & \\
\hline V & 4 & 1 & 300 & 282 & 94,0 & 107 & 51,4 & \\
\hline V & 4 & 2 & 300 & 299 & 99,7 & 75 & 49,3 & \\
\hline V & 5 & 1 & 500 & 440 & 88,0 & 85 & 47,1 & \\
\hline V & 5 & 2 & 500 & 491 & 98,2 & 114 & 55,5 & \\
\hline V & 6 & 1 & 500 & 363 & 72,6 & 78 & 46,2 & \\
\hline
\end{tabular}




$\begin{array}{llllllrl}\text { V } & 6 & 2 & 500 & 470 & 94,0 & 111 & 48,6 \\ \text { VI } & 1 & 1 & 200 & 187 & 93,5 & 89 & 53,6 \\ \text { VI } & 1 & 2 & 325 & 291 & 89,5 & 93 & 67,1 * \\ \text { VI } & 2 & 1 & 300 & 244 & 81,3 & 74 & 47,3 \\ \text { VI } & 2 & 2 & 300 & 295 & 98,3 & 83 & 56,6 \\ \text { VI } & 3 & 1 & 300 & 270 & 90,0 & 73 & 49,3 \\ \text { VI } & 3 & 2 & 300 & 263 & 87,7 & 116 & 56,0 \\ \text { VI } & 4 & 1 & 300 & 274 & 91,3 & 112 & 52,7 \\ \text { VI } & 4 & 2 & 300 & 279 & 93,0 & 96 & 58,3 \\ \text { VI } & 5 & 1 & 500 & 409 & 81,8 & 96 & 47,9 \\ \text { VI } & 5 & 2 & 500 & 419 & 83,8 & 78 & 57,7 \\ \text { VI } & 6 & 1 & 500 & 403 & 80,6 & 94 & 52,1 \\ \text { VI } & 6 & 2 & 500 & 422 & 84,4 & 96 & 56,3 \\ \text { VI } & 7 & 1 & 500 & 358 & 71,6 & 95 & 48,4 \\ \text { VI } & 7 & 2 & 500 & 452 & 90,4 & 88 & 53,4 \\ \text { VI } & 8 & 1 & 500 & 367 & 73,4 & 103 & 47,6 \\ \text { VI } & 8 & 2 & 500 & 363 & 72,6 & 91 & 58,2 \\ \text { VI } & 9 & 1 & 500 & 373 & 74,6 & 78 & 51,3 \\ \text { VI } & 9 & 2 & 500 & 324 & 64,8 & 91 & 56,0 \\ \text { VI } & 10 & 1 & 500 & 348 & 69,6 & 102 & 47,1 \\ \text { VI } & 10 & 2 & 500 & 402 & 80,4 & 97 & 63,9 * * \\ \text { VI } & 11 & 1 & 500 & 336 & 67,2 & 95 & 47,4 \\ \text { VI } & 11 & 2 & 500 & 421 & 84,2 & 88 & 61,4\end{array}$

${ }^{\mathrm{T}}$ Treatment: $1=$ full sib control group continuously at $12{ }^{\circ} \mathrm{C} ; 2=$ treatment at $18{ }^{\circ} \mathrm{C}$ for 30 days, starting at $42 \mathrm{dpf}$;

${ }^{2}$ Survival rate $=$ survival rates after treatment; $\mathrm{SR}=\operatorname{sex}$ ratio;

$3 * * *=$ significantly different from full sib control group $(P<0.05,0.01)$. 
$\underline{\text { Raw data of temperature effects in the breeding base, shown in table } 1 \text { of the publication no. } 2}$

\begin{tabular}{|c|c|c|c|c|c|c|c|}
\hline Treatment $^{1}$ & Mother No. ${ }^{2}$ & Father No. ${ }^{2}$ & $\begin{array}{c}N \text { in } \\
\text { Treatment }\end{array}$ & Survival rate ${ }^{3}$ & $N$ sexed & $\begin{array}{l}\text { Sex ratio } \\
\text { In } \%\end{array}$ & Sig. ${ }^{4}$ \\
\hline 1 & 14 & 42 & 207 & 88,4 & 126 & 48,4 & \\
\hline 2 & 14 & 42 & 300 & 93,3 & 121 & 66,9 & $* *$ \\
\hline 1 & 14 & 29 & 300 & 89,7 & 113 & 46,9 & \\
\hline 2 & 14 & 29 & 300 & 92,3 & 106 & 55,7 & $* *$ \\
\hline 1 & 14 & 34 & 282 & 96,5 & 117 & 45,3 & \\
\hline 2 & 14 & 34 & 283 & 96,8 & 123 & 58,5 & $*$ \\
\hline 1 & 40 & 46 & 300 & 90,7 & 131 & 47,3 & \\
\hline 2 & 40 & 46 & 300 & 93,7 & 127 & 62,2 & $*$ \\
\hline 1 & 40 & 27 & 300 & 88 & 116 & 51,7 & \\
\hline 2 & 40 & 27 & 300 & 90,3 & 119 & 59,7 & $*$ \\
\hline 1 & 40 & 33 & 300 & 87 & 136 & 50,7 & \\
\hline 2 & 40 & 33 & 300 & 92,7 & 69 & 56,5 & \\
\hline 1 & 35 & 33 & 300 & 97 & 119 & 47,1 & \\
\hline 2 & 35 & 33 & 300 & 98,3 & 122 & 56,6 & \\
\hline 1 & 3 & 42 & 400 & 92 & 107 & 52,3 & \\
\hline 2 & 3 & 42 & 400 & 96,5 & 131 & 67,2 & $*$ \\
\hline 1 & 30 & 42 & 400 & 90,5 & 124 & 47,6 & \\
\hline 2 & 30 & 42 & 400 & 91,3 & 104 & 50 & \\
\hline 1 & 33 & 43 & 400 & 87,5 & 127 & 48,8 & \\
\hline 2 & 33 & 43 & 400 & 87,8 & 102 & 64,7 & $*$ \\
\hline 1 & 33 & 29 & 316 & 84,8 & 114 & 51,8 & \\
\hline 2 & 33 & 29 & 400 & 85,3 & 115 & 57,4 & \\
\hline 1 & 33 & 33 & 306 & 91,5 & 117 & 51,3 & \\
\hline 2 & 33 & 33 & 400 & 93,3 & 122 & 55,7 & \\
\hline 1 & 39 & 29 & 400 & 81 & 98 & 52 & \\
\hline 2 & 39 & 29 & 400 & 99,3 & 128 & 59,4 & \\
\hline
\end{tabular}




$\begin{array}{rrrrllr}1 & 39 & 42 & 318 & 74,2 & 110 & 37,3 \\ 2 & 39 & 42 & 400 & 94,8 & 121 & 59,5 * * \\ 1 & 12 & 29 & 339 & 89,9 & 115 & 51,3 \\ 2 & 12 & 29 & 400 & 95 & 132 & 58,3 \\ 1 & 12 & 42 & 235 & 81,3 & 131 & 48,9 \\ 2 & 12 & 42 & 300 & 93,7 & 137 & 57,7 \\ 1 & 4 & 29 & 400 & 79 & 120 & 49,2 \\ 2 & 4 & 29 & 400 & 93 & 131 & 61,1 \\ 1 & 4 & 42 & 255 & 89 & 115 & 41,7 \\ 2 & 4 & 42 & 300 & 89,3 & 128 & 58,6 * * \\ 1 & 80 & 33 & 302 & 90,7 & 121 & 47,5 \\ 2 & 80 & 33 & 400 & 94,5 & 84 & 63,1 \\ 1 & 80 & 29 & 395 & 87,6 & 106 & 49,1 \\ 2 & 80 & 29 & 350 & 90,5 & 132 & 62,1 \\ 1 & 80 & 42 & 400 & 86,9 & 123 & 51,2 \\ 2 & 80 & 42 & 400 & 92,7 & 124 & 62,9 \\ 1 & 47 & 33 & 300 & 91,3 & 117 & 53,8 \\ 2 & 47 & 33 & 300 & 90,8 & 132 & 54,5 \\ 1 & 47 & 29 & 334 & 92,2 & 128 & 50,8 \\ 2 & 47 & 29 & 334 & 94,1 & 128 & 53,1 \\ 1 & 47 & 42 & 400 & 90,3 & 88 & 51,1 \\ 2 & 47 & 42 & 400 & 92,9 & 114 & 64 \\ 1 & 56 & 29 & 400 & 93,5 & 107 & 55,1 \\ 2 & 56 & 29 & 400 & 96 & 119 & 53,8 \\ 1 & 49 & 29 & 400 & 84,5 & 103 & 61,2 \\ 2 & 49 & 29 & 400 & 95,5 & 120 & 62,5 \\ 1 & 49 & 42 & 300 & 81,3 & 89 & 47,2 \\ 2 & 49 & 42 & 300 & 96,3 & 106 & 61,9 \\ 1 & 40 & 48 & 199 & 88,9 & 110 & 105 \\ 2 & 48 & 150 & 89,3 & & \end{array}$




$\begin{array}{rrrlllr}1 & 33 & 48 & 222 & 81,1 & 132 & 53 \\ 2 & 33 & 48 & 222 & 83,8 & 102 & 62,7 \\ 1 & 81 & 48 & 300 & 79 & 123 & 48 \\ 2 & 81 & 48 & 300 & 84,5 & 133 & 55,3 \\ 1 & 17 & 63 & 300 & 90,3 & 109 & 49,5 \\ 2 & 17 & 63 & 300 & 88 & 93 & 61,3 \\ 1 & 40 & 63 & 300 & 74,7 & 108 & 51,9 \\ 2 & 40 & 63 & 300 & 87,7 & 112 & 58,9 \\ 1 & 33 & 63 & 300 & 81 & 127 & 48,8 \\ 2 & 33 & 63 & 300 & 87,3 & 106 & 65,1 \\ 1 & 65 & 64 & 300 & 94,7 & 124 & 48,4 \\ 2 & 65 & 64 & 300 & 91,7 & 114 & 50 \\ 1 & 65 & 48 & 300 & 81 & 126 & 47,6 \\ 2 & 65 & 48 & 300 & 85,3 & 128 & 60,9 * \\ 1 & 82 & 48 & 260 & 95,4 & 121 & 47,9 \\ 2 & 82 & 48 & 260 & 96,5 & 129 & 58,9 \\ 1 & 39 & 48 & 300 & 88,7 & 132 & 53 \\ 2 & 39 & 48 & 300 & 87 & 133 & 59,4 \\ 1 & 72 & 61 & 300 & 82 & 135 & 48,1 \\ 2 & 72 & 61 & 300 & 85 & 121 & 49,6 \\ 1 & 80 & 53 & 300 & 65,3 & 112 & 48,2 \\ 2 & 80 & 53 & 300 & 89,3 & 103 & 51,5 \\ 1 & 14 & 53 & 300 & 68,7 & 116 & 50 \\ 2 & 14 & 53 & 300 & 79,3 & 112 & 60,7 \\ 1 & 74 & 53 & 350 & 82 & 130 & 47,7 \\ 2 & 74 & 53 & 350 & 93,1 & 124 & 49,2 \\ 1 & 74 & 61 & 350 & 84,9 & 125 & 47,2 \\ 2 & 35 & 33 & 350 & 88,3 & 120 & 48,3 \\ 1 & 33 & 500 & 67,4 & 101 & 56,2 \\ 2 & 50 & 500 & 81,6 & 89 & \end{array}$




$\begin{array}{rrrrrrr}1 & \text { N6 } & \text { N6 } & 200 & 85,0 & 85 & 48,8 \\ 2 & \text { N6 } & \text { N6 } & 200 & 91,5 & 112 & 65,8 \\ 2 & \text { N2 } & \text { N2 } & 200 & 83,5 & 84 & 51,2 \\ 1 & \text { N2 } & \text { N2 } & 200 & 89,5 & 165 & 59,5 \\ 2 & 14 & 35 & 500 & 74,2 & 25 & 48 \\ 1 & 14 & 35 & 500 & 81,3 & 85 & 69,4 * \\ 2 & 36 & 20 & 500 & 69,6 & 98 & 48,8 \\ 1 & 36 & 20 & 500 & 80,4 & 97 & 63,9 * * \\ 2 & 3 & 42 & 500 & 67,2 & 95 & 47,4 \\ 1 & 3 & 42 & 500 & 84,2 & 88 & 61,4 \\ 2 & 47 & 50 & 500 & 89,4 & 79 & 52 \\ 1 & 47 & 50 & 500 & 95,8 & 92 & 58,7 \\ 2 & 12 & 41 & 300 & 81,3 & 74 & 47,3 \\ 1 & 12 & 41 & 300 & 98,3 & 83 & 56,6 \\ 2 & 23 & 41 & 300 & 90,0 & 73 & 49,3 \\ 1 & 23 & 41 & 300 & 87,8 & 116 & 56 \\ 2 & 46 & 46 & 500 & 96,2 & 92 & 47,8 \\ 1 & 46 & 46 & 500 & 94,6 & 90 & 34,4 \\ 2 & 53 & 49 & 500 & 95,6 & 92 & 48,9 \\ 1 & 53 & 49 & 500 & 98,4 & 89 & 43,8 \\ 2 & 52 & 46 & 500 & 91,4 & 90 & 53 \\ 1 & 52 & 46 & 500 & 94,6 & 90 & 36,7 \\ 2 & 11 & 29 & 110 & 72,7 & 86 & 53,5 \\ 1 & 11 & 29 & 90 & 84,4 & 89 & 38,2 \\ 2 & 3 & 29 & 340 & 91,2 & 124 & 47,6 \\ 1 & 3 & 29 & 400 & 85,3 & 120 & 44,2 \\ 2 & 3 & 33 & 146 & 89,7 & 52 & 53,8 \\ 1 & 3 & 33 & 400 & 90,5 & 86 & 39,3 \\ 2 & 30 & 29 & 400 & 92,5 & 112 & * \\ & 30 & 29 & 400 & 94,3 & 101 & \end{array}$




\begin{tabular}{|c|c|c|c|c|c|c|}
\hline 1 & 30 & 33 & 191 & 84,8 & 92 & 46,7 \\
\hline 2 & 30 & 33 & 191 & 95,3 & 113 & 39,8 \\
\hline 1 & 39 & 33 & 164 & 97,6 & 115 & 52,2 \\
\hline 2 & 39 & 33 & 200 & 96,0 & 123 & 43,9 \\
\hline 1 & 12 & 33 & 178 & 92,0 & 108 & 51,9 \\
\hline 2 & 12 & 33 & 300 & 96,2 & 117 & 41,9 \\
\hline 1 & 59 & 29 & 400 & 83,5 & 109 & 51,4 \\
\hline 2 & 59 & 29 & 400 & 81,3 & 111 & 40,5 \\
\hline 1 & 72 & 29 & 400 & 86,5 & 111 & 50,5 \\
\hline 2 & 72 & 29 & 400 & 87,3 & 108 & 40,7 \\
\hline 1 & 66 & 33 & 400 & 76,5 & 82 & 51,2 \\
\hline 2 & 66 & 33 & 400 & 92,3 & 106 & 42,5 \\
\hline 1 & 56 & 33 & 400 & 76,5 & 94 & 51,2 \\
\hline 2 & 56 & 33 & 376 & 94,8 & 109 & 41,3 \\
\hline 1 & 67 & 29 & 400 & 80,5 & 68 & 51,5 \\
\hline 2 & 67 & 29 & 400 & 91,3 & 129 & 48,8 \\
\hline 1 & 52 & 43 & 400 & 86,3 & 117 & 51,3 \\
\hline 2 & 52 & 43 & 400 & 93,8 & 116 & 50,9 \\
\hline 1 & 35 & 61 & 300 & 81,7 & 109 & 49,5 \\
\hline 2 & 35 & 61 & 300 & 88,7 & 92 & 41,9 \\
\hline 1 & 40 & 61 & 300 & 87,0 & 120 & 52,5 \\
\hline 2 & 40 & 61 & 300 & 90,3 & 91 & 52,7 \\
\hline 1 & 33 & 61 & 300 & 76,3 & 124 & 47,6 \\
\hline 2 & 33 & 61 & 300 & 83,7 & 90 & 48,9 \\
\hline 1 & 81 & 61 & 300 & 69,3 & 110 & 50,9 \\
\hline 2 & 81 & 61 & 300 & 88,0 & 114 & 40,4 \\
\hline 1 & 65 & 61 & 300 & 76,7 & 129 & 51,2 \\
\hline 2 & 65 & 61 & 300 & 95,3 & 93 & 48,4 \\
\hline 1 & 82 & 61 & 300 & 69,3 & 131 & 46,6 \\
\hline 2 & 82 & 61 & 300 & 93,0 & 102 & 45,1 \\
\hline
\end{tabular}




$\begin{array}{rrrrrrr}1 & 39 & 61 & 300 & 89,7 & 117 & 47,9 \\ 2 & 39 & 61 & 300 & 94,0 & 119 & 47,9 \\ 1 & 44 & 64 & 300 & 87,7 & 119 & 47,1 \\ 2 & 44 & 64 & 300 & 87,7 & 99 & 41,4 \\ 1 & 39 & 64 & 300 & 92,3 & 130 & 50 \\ 2 & 39 & 64 & 300 & 97,3 & 103 & 41,7 \\ 1 & 72 & 53 & 300 & 79,7 & 125 & 49,6 \\ 2 & 72 & 53 & 300 & 80,3 & 119 & 47,1 \\ 1 & 72 & 64 & 300 & 73,7 & 117 & 49,6 \\ 2 & 72 & 64 & 300 & 86,3 & 119 & 42,9 \\ 1 & 74 & 64 & 350 & 81,1 & 126 & 47,6 \\ 2 & 74 & 64 & 350 & 94,0 & 121 & 43,8 \\ 1 & 52 & 53 & 350 & 87,4 & 113 & 51,3 \\ 2 & 52 & 53 & 300 & 96,0 & 107 & 46,7 \\ 1 & 52 & 64 & 335 & 91,6 & 103 & 53,4 \\ 2 & 52 & 64 & 350 & 97,4 & 126 & 43,7 \\ 1 & 52 & 61 & 200 & 85,5 & 107 & 45,8 \\ 2 & 52 & 61 & 300 & 92,0 & 116 & 41,9 \\ 1 & 60 & 53 & 350 & 86,3 & 114 & 50,9 \\ 2 & 60 & 53 & 350 & 95,4 & 108 & 46,3 \\ 1 & 60 & 64 & 350 & 89,4 & 96 & 49 \\ 2 & 60 & 64 & 350 & 95,1 & 118 & 48,3 \\ 1 & 60 & 61 & 350 & 79,4 & 94 & 48,9 \\ 2 & 60 & 61 & 350 & 92,0 & 104 & 41,3 \\ 1 & 63 & 61 & 350 & 85,7 & 107 & 52,3 \\ 2 & 63 & 61 & 350 & 94,3 & 109 & 45,9 \\ 1 & 63 & 64 & 300 & 81,7 & 112 & 47,4 \\ 2 & 55 & 64 & 340 & 91,8 & 100 & 40,8 \\ 1 & 61 & 350 & 88,0 & 105 & 43,6 \\ 2 & 61 & 350 & 91,4 & 99 & \end{array}$




\begin{tabular}{rllllll}
1 & 55 & 64 & 200 & 78 & 101 & 49 \\
2 & 55 & 64 & 278 & 88,5 & 92 & 39,1 \\
1 & 68 & 61 & 350 & 86,9 & 104 & 46,2 \\
2 & 68 & 61 & 350 & 93,4 & 105 & 43,8 \\
1 & 68 & 64 & 300 & 81,3 & 58 & 48,1 \\
2 & 68 & 64 & 350 & 97,7 & 102 & 41,2 \\
1 & 57 & 64 & 350 & 85,1 & 90 & 52,2 \\
2 & 57 & 64 & 350 & 93,1 & 103 & 39,8 \\
1 & 49 & 48 & 500 & 90,2 & 81 & 49,4 \\
2 & 49 & 48 & 500 & 93,2 & 91 & 45,1 \\
1 & 48 & 52 & 500 & 76,6 & 114 & 48,2 \\
2 & 48 & 52 & 500 & 74 & 94 & 44,7 \\
1 & 55 & 60 & 500 & 78,8 & 97 & 49,5 \\
2 & 55 & 60 & 500 & 79,2 & 102 & 44,1 \\
\hline
\end{tabular}

Treatment: $1=$ full sib control group kept continuously at $12{ }^{\circ} \mathrm{C} ; 2=$ treatment group kept at $18{ }^{\circ} \mathrm{C}$ for 30 days starting $42 \mathrm{dpf}$.;

${ }^{2}$ Mother-No.= number of the female spawner of the mating; Father-No.= number of the male spawner of the mating;

${ }^{3}$ Survival rate $=$ survival rate after temperature treatment; $\mathrm{SR}=$ sex ratio;

$4 *, * *=$ significantly different from the full sib controls $(P<0.05,0.01)$. 
$\underline{\text { Raw data of realized response to selection, shown in table } 1 \text { of publication no. } 2}$

\begin{tabular}{|c|c|c|c|c|c|c|c|c|}
\hline $\begin{array}{l}\text { Line, } \\
\text { Mating }\end{array}$ & Treatment $^{1}$ & Mother-No. $^{2}$ & Father-No. $^{2}$ & $\begin{array}{l}N \text { after } \\
\text { Treatment }\end{array}$ & $\begin{array}{l}\text { Survival- } \\
\text { rate }^{3}, \%\end{array}$ & $N$ sexed & $\begin{array}{l}\text { Sex ratio } \\
\text { In } \%\end{array}$ & Sig. $^{4}$ \\
\hline \multicolumn{9}{|l|}{$\underline{\text { High }}$} \\
\hline 1 & 1 & 79 & 61 & 276 & 92,0 & 104 & 51,9 & \\
\hline 1 & 2 & 79 & 61 & 283 & 94,3 & 106 & 54,7 & \\
\hline 2 & 1 & 79 & 45 & 275 & 91,7 & 96 & 47,9 & \\
\hline 2 & 2 & 79 & 45 & 283 & 94,3 & 99 & 55,6 & \\
\hline 3 & 1 & 79 & 47 & 280 & 93,3 & 83 & 48,2 & \\
\hline 3 & 2 & 79 & 47 & 286 & 95,3 & 109 & 52,3 & \\
\hline 4 & 1 & 74 & 61 & 255 & 85,0 & 90 & 51,1 & \\
\hline 4 & 2 & 74 & 61 & 278 & 92,7 & 99 & 58,6 & \\
\hline 5 & 1 & 74 & 45 & 260 & 86,7 & 120 & 48,3 & \\
\hline 5 & 2 & 74 & 45 & 281 & 93,7 & 100 & 72,0 & $*$ \\
\hline 6 & 1 & 74 & 47 & 287 & 95,7 & 108 & 48,1 & \\
\hline 6 & 2 & 74 & 47 & 272 & 90,7 & 102 & 57,8 & \\
\hline 7 & 1 & 65 & 61 & 290 & 96,7 & 109 & 47,7 & \\
\hline 7 & 2 & 65 & 61 & 284 & 94,7 & 106 & 58,5 & \\
\hline 8 & 1 & 65 & 45 & 283 & 94,3 & 88 & 51,1 & \\
\hline 8 & 2 & 65 & 45 & 286 & 95,3 & 121 & 57,0 & \\
\hline 9 & 1 & 65 & 47 & 271 & 90,3 & 115 & 48,7 & \\
\hline 9 & 2 & 65 & 47 & 291 & 97,0 & 127 & 58,3 & \\
\hline 10 & 1 & 39 & 61 & 272 & 90,7 & 112 & 48,2 & \\
\hline 10 & 2 & 39 & 61 & 266 & 88,7 & 123 & 53,7 & \\
\hline 11 & 1 & 39 & 45 & 270 & 90,0 & 112 & 49,1 & \\
\hline 11 & 2 & 39 & 45 & 260 & 86,7 & 117 & 58,1 & \\
\hline 12 & 1 & 39 & 47 & 266 & 88,7 & 111 & 52,3 & \\
\hline 12 & 2 & 39 & 47 & 287 & 95,7 & 105 & 56,2 & \\
\hline 13 & 1 & 73 & 61 & 299 & 85,4 & 109 & 51,4 & \\
\hline
\end{tabular}




$\begin{array}{rrrrrrrr}13 & 2 & 73 & 61 & 302 & 86,3 & 94 & 59,6 \\ 14 & 1 & 73 & 59 & 275 & 78,6 & 98 & 48,0 \\ 14 & 2 & 73 & 59 & 312 & 89,1 & 110 & 60,9 * \\ 15 & 1 & 73 & 44 & 282 & 80,6 & 97 & 51,5 \\ 15 & 2 & 73 & 44 & 286 & 81,7 & 94 & 48,6 \\ 16 & 1 & 45 & 61 & 275 & 91,7 & 95 & 51,6 \\ 16 & 2 & 45 & 61 & 282 & 94,0 & 115 & 58,3 \\ 17 & 1 & 45 & 59 & 245 & 81,7 & 100 & 47,0 \\ 17 & 2 & 45 & 59 & 279 & 93,0 & 99 & 60,6 \\ 18 & 1 & 45 & 44 & 278 & 92,7 & 95 & 48,4 \\ 18 & 2 & 45 & 44 & 288 & 96,0 & 115 & 56,5\end{array}$

$\begin{array}{cccccrrr}\frac{\text { Low }}{1} & 1 & 64 & 59 & 279 & 79,7 & 96 & 50,0 \\ 1 & 2 & 64 & 59 & 297 & 84,9 & 121 & 48,8 \\ 2 & 1 & 64 & 44 & 293 & 83,7 & 100 & 45,0 \\ 2 & 2 & 64 & 44 & 280 & 80,0 & 119 & 46,2 \\ 3 & 1 & 61 & 59 & 304 & 86,9 & 110 & 49,1 \\ 3 & 2 & 61 & 59 & 279 & 79,7 & 98 & 43,9 \\ 4 & 1 & 61 & 44 & 317 & 90,6 & 102 & 52,0 \\ 4 & 2 & 61 & 44 & 294 & 84,0 & 109 & 45,9 \\ 5 & 1 & 78 & 44 & 275 & 91,7 & 109 & 52,3 \\ 5 & 2 & 78 & 44 & 286 & 95,3 & 103 & 41,7 \\ 6 & 1 & 78 & 59 & 245 & 81,7 & 120 & 49,2 \\ 6 & 2 & 78 & 59 & 266 & 88,7 & 99 & 43,4 \\ 7 & 1 & 71 & 44 & 257 & 85,7 & 105 & 47,6 \\ 7 & 2 & 71 & 44 & 268 & 89,3 & 115 & 47,8 \\ 8 & 1 & 71 & 59 & 263 & 87,7 & 94 & 52,1 \\ 8 & 2 & 71 & 59 & 288 & 96,0 & 111 & 38,7\end{array}$




\begin{tabular}{llllllrl}
9 & 1 & 77 & 44 & 242 & 80,7 & 108 & 50,9 \\
9 & 2 & 77 & 44 & 282 & 94,0 & 102 & 49,0 \\
10 & 1 & 77 & 59 & 270 & 90,0 & 107 & 47,7 \\
10 & 2 & 77 & 59 & 284 & 94,7 & 96 & $32,5 *$ \\
11 & 1 & 78 & 60 & 256 & 85,3 & 108 & 48,1 \\
11 & 2 & 78 & 60 & 277 & 92,3 & 94 & 44,7 \\
12 & 1 & 78 & 65 & 268 & 89,3 & 104 & 51,0 \\
12 & 2 & 78 & 65 & 288 & 96,0 & 96 & 43,8 \\
13 & 1 & 79 & 60 & 269 & 89,7 & 93 & 51,6 \\
13 & 2 & 79 & 60 & 281 & 93,7 & 90 & 45,6 \\
14 & 1 & 79 & 65 & 283 & 94,3 & 109 & 48,6 \\
14 & 2 & 79 & 65 & 292 & 97,3 & 102 & 44,1 \\
\hline
\end{tabular}

Treatment: $1=$ full sib control group kept continuously at $12{ }^{\circ} \mathrm{C} ; 2=$ treatment group kept at $18{ }^{\circ} \mathrm{C}$ for 30 days starting 42 dpf.;

${ }^{2}$ Mother-No.= number of the female spawner of the mating; Father-No.= number of the male spawner of the mating;

${ }^{3}$ Survival rate=survival rate after temperature treatment; $\mathrm{SR}=$ sex ratio.

$4 *$ significantly different from the full sib controls $(P<0.05)$. 
Raw data (in gram) for the body weight comparison between the treated fish and the full sib control groups, shown in publication no. 2

\begin{tabular}{|c|c|c|c|c|c|}
\hline Treatment & Control & Treatment & Control & Treatment & Control \\
\hline 265,3 & 248,8 & 248,9 & 292,5 & 251,1 & 279,3 \\
\hline 256,4 & 254,3 & 244,0 & 287,3 & 278,9 & 287,3 \\
\hline 302,3 & 269,5 & 313,4 & 248,7 & 282,0 & 267,3 \\
\hline 276,4 & 287,3 & 298,6 & 324,1 & 291,2 & 297,4 \\
\hline 263,1 & 277,3 & 304,8 & 308,1 & 287,6 & 280,5 \\
\hline 247,6 & 271,4 & 294,3 & 275,4 & 255,4 & 274,2 \\
\hline 266,7 & 270,0 & 257,3 & 286,5 & 267,1 & 278,4 \\
\hline 281,0 & 284,1 & 299,1 & 304,6 & 274,3 & 284,3 \\
\hline 244,6 & 289,8 & 308,4 & 301,7 & 276,4 & 297,9 \\
\hline 257,9 & 257,3 & 267,9 & 287,3 & 281,3 & 309,8 \\
\hline 266,1 & 271,0 & 283,7 & 291,6 & 274,5 & 285,6 \\
\hline 268,9 & 279,3 & 281,5 & 293,4 & 268,9 & 297,2 \\
\hline 278,3 & 287,3 & 286,3 & 268,3 & 268,4 & 293,4 \\
\hline 268,6 & 267,3 & 276,4 & 287,8 & 276,8 & 289,7 \\
\hline 300,8 & 297,4 & 296,4 & 282,2 & 288,2 & 291,4 \\
\hline 289,0 & 280,5 & 291,0 & 291,3 & 297,6 & 295,4 \\
\hline 285,4 & 274,2 & 255,6 & 266,7 & 258,4 & 304,6 \\
\hline 277,4 & 278,4 & 249,7 & 289,6 & 287,0 & 300,8 \\
\hline 275,1 & 284,3 & 264,3 & 290,8 & 268,4 & 284,5 \\
\hline 273,0 & 297,9 & 268,4 & 273,5 & 282,8 & 281,4 \\
\hline 275,1 & 309,8 & 271,3 & 286,4 & 286,7 & 292,3 \\
\hline 279,2 & 285,6 & 274,1 & 283,0 & 278,3 & 293,1 \\
\hline 269,4 & 298,5 & 275,9 & 314,0 & 248,8 & 276,4 \\
\hline 266,8 & 278,6 & 277,8 & 290,1 & 254,3 & 259,3 \\
\hline 294,0 & 285,4 & 276,4 & 287,3 & 269,5 & 285,4 \\
\hline 275,4 & 287,3 & 287,6 & 276,4 & 287,3 & 287,3 \\
\hline 279,1 & 304,2 & 275,1 & 287,6 & 277,3 & 332,1 \\
\hline 285,7 & 300,4 & 288,4 & 299,4 & 271,4 & 300,4 \\
\hline 286,4 & 284,1 & 273,3 & 284,2 & 264,9 & 284,1 \\
\hline 290,8 & 290,1 & 286,1 & 287,8 & 270,0 & 290,1 \\
\hline 274,8 & 294,3 & 281,1 & 288,0 & 284,1 & 290,8 \\
\hline 268,4 & 283,7 & 304,6 & 291,4 & 289,8 & 289,3 \\
\hline 279,1 & 290,7 & 282,6 & 290,6 & 271,7 & 286,5 \\
\hline 248,8 & 271,4 & 271,4 & 285,2 & 285,4 & 312,5 \\
\hline 254,3 & 291,2 & 270,0 & 295,1 & 287,3 & 271,4 \\
\hline 269,5 & 284,1 & 284,1 & 285,0 & 274,0 & 270,0 \\
\hline 287,3 & 291,1 & 289,8 & 269,5 & 274,2 & 284,1 \\
\hline 290,4 & 271,4 & 295,5 & 287,3 & 284,1 & 289,8 \\
\hline 271,4 & 296,4 & 291,8 & 277,3 & 280,4 & 296,4 \\
\hline 296,4 & 284,1 & 255,6 & 281,9 & 271,4 & 291,0 \\
\hline
\end{tabular}




\section{Acknowledgement}

I wish to express my deep gratitude to Prof. Dr. Hörstgen-Schwark for the acceptance of this thesis, for the great assistance I got at all times and for giving me the opportunity to accomplish this $\mathrm{PhD}$ - work in the interesting aquaculture field. In addition to this, I have to thank Prof. Dr. Hörstgen-Schwark very much that I could have a wonderful and unforgettable visit to Chiang May University in the summer 2007, which gave me many new ideas, experiences and of course it also took benefit to my scientific work.

Furthermore, I would like to express my gratitude to Prof. Dr. Dr. ter Meulen for being the second referee of my $\mathrm{PhD}$ - thesis, as well as Prof. Dr. Lücke for being my third referee.

In addition, I am proud that I can express my appreciation to the whole 'Aquaculture team', namely Dr. Müller-Belecke, Dr. Stefan Wessels, my friend Daniel Kaffke (died at Nov. $20^{\text {th }}$,2006) , Heiko Hartmann, Birgit Reinelt, Uwe Schipke and my PhD colleagues Boris de Lapeyre, Eduard Onumah, Liane Lühmann who all contributed to this work in more ways than one.

Last but not least, for their constant moral and financial support, my special thanks go to my parents and my siblings, in particular to my sister Susanne and Oriana Harte, as a native speaker from Oxford, for being wonderful correctors and reviewers of my written English. 


\section{Curriculum vitae}

Name: Magerhans

Vorname: Andreas

Geburtsdatum: 4. November 1977

Heimatort: Göttingen

\section{Berufliche Tätigkeit}

Seit 05/2005 Doktorand, Institut für Tierzucht und Haustiergenetik,

Georg-August-Universität Göttingen, D-37075 Göttingen

\section{Studium}

1998 - 2000 Studium der Rechtswissenschaften, Universität Göttingen

2001 - 2005 Studium der Agrarwissenschaften, Fachrichtung Wirtschafts- und Sozialwissenschaften des Landbaus, Universität Göttingen, D-37075 Göttingen

\section{Schulen}

1984 - 1988 Grundschule Waake

1988 - 1990 Orientierungsstufe Nord Göttingen

1990 - 1997 Hainberg - Gymnasium Göttingen

\section{Praktika}

07-10/2001 Landwirtschaftlicher Ausbildungsbetrieb der

Familie Henneke GbR, 37130 Elbickerode

\section{Wehrdienst}

1997 - 1998 Lippstadt, 2./4. Transportbataillon 801 